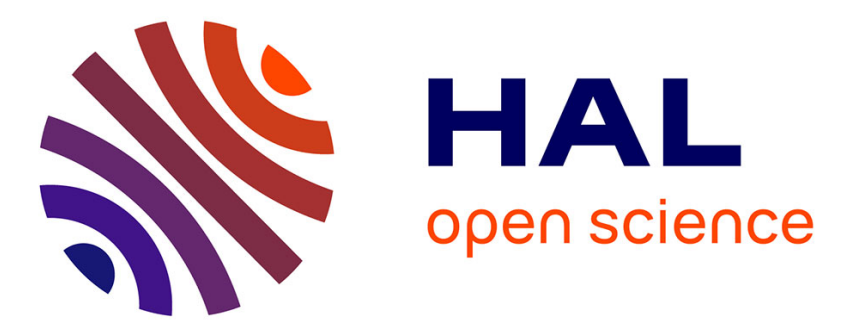

\title{
Acute interactions between intestinal sugar and calcium transport in vitro
}

\author{
Phuntila Tharabenjasin, Véronique Douard, Chirag Patel, Nateetip \\ Krishnamra, Richard J. Johnson, Jian Zuo, Ronaldo P Ferraris
}

\section{- To cite this version:}

Phuntila Tharabenjasin, Véronique Douard, Chirag Patel, Nateetip Krishnamra, Richard J. Johnson, et al.. Acute interactions between intestinal sugar and calcium transport in vitro. AJP - Gastrointestinal and Liver Physiology, 2014, 306 (1), pp.G1-12. 10.1152/ajpgi.00263.2013 . hal-01608146

\section{HAL Id: hal-01608146 https://hal.science/hal-01608146}

Submitted on 27 May 2020

HAL is a multi-disciplinary open access archive for the deposit and dissemination of scientific research documents, whether they are published or not. The documents may come from teaching and research institutions in France or abroad, or from public or private research centers.
L'archive ouverte pluridisciplinaire HAL, est destinée au dépôt et à la diffusion de documents scientifiques de niveau recherche, publiés ou non, émanant des établissements d'enseignement et de recherche français ou étrangers, des laboratoires publics ou privés.

\section{다(1)(2)}

Distributed under a Creative Commons Attribution - ShareAlikel 4.0 International 


\title{
Acute interactions between intestinal sugar and calcium transport in vitro
}

\author{
Phuntila Tharabenjasin, ${ }^{1,2,3}$ Veronique Douard, ${ }^{1}$ Chirag Patel, ${ }^{1}$ Nateetip Krishnamra, ${ }^{2,3}$ \\ Richard J. Johnson, ${ }^{4}$ Jian Zuo, ${ }^{5}$ and Ronaldo P. Ferraris ${ }^{1}$ \\ ${ }^{1}$ Department of Pharmacology and Physiology, Rutgers Biomedical and Health Sciences, New Jersey Medical School (NJMS), \\ Newark, New Jersey; ${ }^{2}$ Exercise Science Graduate Program, Department of Physiology, and ${ }^{3}$ Center of Calcium and Bone \\ Research (COCAB), Faculty of Science, Mahidol University, Bangkok, Thailand; ${ }^{4}$ The Division of Renal Diseases \\ and Hypertension, Department of Medicine, University of Colorado, Aurora, Colorado; ${ }^{5}$ Department of Developmental \\ Neurobiology, St. Jude Children's Research Hospital, Memphis, Tennessee
}

Submitted 12 August 2013; accepted in final form 24 October 2013

\begin{abstract}
Tharabenjasin P, Douard V, Patel C, Krishnamra N, Johnson RJ, Zuo J, Ferraris RP. Acute interactions between intestinal sugar and calcium transport in vitro. Am J Physiol Gastrointest Liver Physiol 306: G1-G12, 2014. First published October 31, 2013; doi:10.1152/ajpgi.00263.2013.-Fructose consumption by Americans has increased markedly, whereas $\mathrm{Ca}^{2+}$ intake has decreased below recommended levels. Because fructose metabolism decreases enterocyte ATP concentrations, we tested the hypothesis that luminal fructose acutely reduces active, diet-inducible $\mathrm{Ca}^{2+}$ transport in the small intestine. We confirmed that the decrease in ATP concentrations was indeed greater in fructose- compared with glucose-incubated mucosal homogenates from wild-type and was prevented in fructose-incubated homogenates from ketohexokinase $(\mathrm{KHK})^{-1-}$ mice. We then induced active $\mathrm{Ca}^{2+}$ transport by chronically feeding wild-type, fructose transporter glucose transporter 5 (GLUT5) $^{-1-}$, as well as $\mathrm{KHK}^{-1-}$ mice a low $\mathrm{Ca}^{2+}$ diet and measured transepithelial $\mathrm{Ca}^{2+}$ transport in everted duodenal sacs incubated in solutions containing glucose, fructose, or their nonmetabolizable analogs. The diet-induced increase in active $\mathrm{Ca}^{2+}$ transport was proportional to dramatic increases in expression of the $\mathrm{Ca}^{2+}$-selective channel transient receptor potential vanilloid family calcium channel 6 as well as of the $\mathrm{Ca}^{2+}$-binding protein $9 \mathrm{k}(\mathrm{CaBP} 9 \mathrm{k})$ but not that of the voltage-dependent L-type channel $\mathrm{Ca}(\mathrm{v}) 1.3$. Crypt-villus distribution of CaBP9k seems heterogeneous, but low $\mathrm{Ca}^{2+}$ diets induce expression in more cells. In contrast, KHK distribution is homogeneous, suggesting that fructose metabolism can occur in all enterocytes. Diet-induced $\mathrm{Ca}^{2+}$ transport was not enhanced by addition of the enterocyte fuel glutamine and was always greater in sacs of wild-type, GLUT5 ${ }^{-1-}$, and $\mathrm{KHK}^{-1-}$ mice incubated with fructose or nonmetabolizable sugars than those incubated with glucose. Thus duodenal $\mathrm{Ca}^{2+}$ transport is not affected by fructose and enterocyte ATP concentrations but instead may decrease with glucose metabolism, as $\mathrm{Ca}^{2+}$ transport remains high with 3-O-methylglucose that is also transported by sodium-glucose cotransporter 1 but cannot be metabolized.
\end{abstract}

calbindin; fructose; glucose; glucose transporter 5; metabolism; nutrition

INTESTINAL CALCIUM TRANSPORT has saturable and nonsaturable components and may be passive and paracellular or active and transcellular $(6,8,16,32,40)$. Transepithelial active $\mathrm{Ca}^{2+}$ transport across the enterocyte occurs mainly in the proximal intestine and is thought to consist of three major steps, which are 1) passive $\mathrm{Ca}^{2+}$ entry mainly via the $\mathrm{Ca}^{2+}$-selective channel, transient receptor potential vanilloid family calcium channel 6 (TRPV6), on the apical membrane, 2) $\mathrm{Ca}^{2+}$ translocation

Address for reprint requests and other correspondence: R. Ferraris, Dept. of Pharmacology \& Physiology, Rutgers Biomedical and Health Sciences, New Jersey Medical School (NJMS), 185 South Orange Ave., Newark, NJ 07103 (e-mail: ferraris@njms.rutgers.edu). across the cytoplasm with $\mathrm{Ca}^{2+}$-binding protein $\mathrm{D}_{9} \mathrm{~K}$ (CaBP9k, calbindin), and 3) active $\mathrm{Ca}^{2+}$ extrusion from the enterocyte to the blood by the plasma membrane $\mathrm{Ca}^{2+}$-ATPase isoform $1 \mathrm{~b}$ (PMCA1b) and the $\mathrm{Na}^{+} / \mathrm{Ca}^{2+}$ exchanger isoform 1 (NCX1) (40). Thus the basolateral exit step requires energy either directly via ATP hydrolysis or indirectly via the $\mathrm{Na}^{+}$ gradient. Active transepithelial $\mathrm{Ca}^{2+}$ transport mediated primarily by these transporters is typically very low in adult mammals consuming diets containing normal $\mathrm{Ca}^{2+}$ levels but can be induced mainly in the duodenum by $1,25(\mathrm{OH})_{2} \mathrm{D}_{3}$ during chronic physiological (e.g., growth, pregnancy, and lactation) and nutritional (e.g., dietary $\mathrm{Ca}^{2+}$ deficiency) $\mathrm{Ca}^{2+}$ stress $(6,8,16,32,40)$. This study used low-Ca ${ }^{2+}$, vitamin $\mathrm{D}$-sufficient diets to upregulate $\mathrm{Ca}^{2+}$ transporter activity in the duodenum and is thus concerned primarily with acute effects of sugars on diet-inducible, $1,25(\mathrm{OH})_{2} \mathrm{D}_{3}$-regulated, active $\mathrm{Ca}^{2+}$ transport.

Because it is important for intracellular signaling and for the regulation of cardiac and muscle activity, $\mathrm{Ca}^{2+}$ concentrations in the blood are tightly regulated within a very narrow range, so acute deficiencies are quickly addressed at the expense of $\mathrm{Ca}^{2+}$ stores in the skeleton, whereas chronic deficiencies are typically resolved by adaptive increases in active $\mathrm{Ca}^{2+}$ transport in the small intestine and kidney. Intestinal $\mathrm{Ca}^{2+}$ absorption may depend, not only on dietary $\mathrm{Ca}^{2+}$ and serum vitamin $\mathrm{D}$ concentrations, but also on dietary factors that may alter luminal $\mathrm{Ca}^{2+}$ concentrations or interfere with $\mathrm{Ca}^{2+}$ transporters. Dietary factors that have been shown to affect $\mathrm{Ca}^{2+}$ bioavailability include plant fiber, fat, phosphorus, protein, and carbohydrate $(1,2,9,35)$. Concerning potential interactions between intestinal carbohydrate and $\mathrm{Ca}^{2+}$ absorption, most investigations have focused on the stimulating effect of the milk sugar lactose on the absorption of $\mathrm{Ca}^{2+}(3,14,27,51$, 52 ), as these two nutrients are typically in the intestinal lumen at the same time. Moreover, monosaccharides such as glucose and/or galactose have also been reported to acutely affect intestinal $\mathrm{Ca}^{2+}$ transport $(11,60,69,75)$. There have only been a few studies that evaluated the direct effect of fructose on $\mathrm{Ca}^{2+}$ absorption $(3,69)$, but these early pioneering studies used high luminal fructose concentrations (550 and $160 \mathrm{mM}$ ) and were conducted using sacs of the rat ileum, which expresses few transporters and thus exhibits little active $\mathrm{Ca}^{2+}$ transport (8). More importantly, none of these studies studied the acute effects of sugars on that component of $\mathrm{Ca}^{2+}$ transport that is diet-inducible and thus important during periods of physiological and nutritional $\mathrm{Ca}^{2+}$ stress.

Like diet-inducible active $\mathrm{Ca}^{2+}$ transport, sugar transport also occurs mainly in the proximal intestine (29). Apical glu- 
cose and galactose sodium-glucose cotransporter 1 (SGLT1)mediated transport into the cell is active and electrogenic (72). Depending primarily on the nutritive status of the body, glucose can be metabolized but is generally accumulated to a high concentration in the cytosol for the facilitative glucose transporter 2 (GLUT2)-mediated downhill transport into the blood containing $\sim 5 \mathrm{mM}$ glucose $(15,44)$. In contrast, transepithelial fructose absorption is entirely passive. Uptake across the apical membrane is mediated by GLUT5, whereas basolateral exit is mediated by $\operatorname{GLUT2}(53,65)$. Fructose is not bound to any protein during transit across the cytosol but can be metabolized in the enterocytes $(33,54)$. Compared with glucose metabolism, which is highly regulated, fructose catabolism is irreversibly initiated by the ketohexokinase (KHK, also known as fructokinase) enzyme, which produces fructose-1-phosphate $(19,38)$. After fructose uptake, fructose-1-phosphate is rapidly accumulated, whereas creatine phosphate, ATP, or intracellular Pi concentrations are reduced in the enterocyte $(33,38,45,49$, 54). The mechanism underlying the depletion of energy-rich intermediates and accumulation of fructose-1-phosphate is thought to be the relatively slow activity of downstream enzymes that further catabolize fructose-1-phosphate, compared with that of $\operatorname{KHK}(68,71)$.

How can transport between $\mathrm{Ca}^{2+}$ and fructose, or between $\mathrm{Ca}^{2+}$ and glucose, possibly interact, as their intestinal absorption involves completely different apical, intracellular, and basolateral proteins? This question is timely because a growing number of modern dairy products that are used as primary nutritive $\mathrm{Ca}^{2+}$ sources (55) is now sweetened with highfructose corn syrups (HFCS), which usually contain 55\% fructose and $45 \%$ glucose (36). Moreover, fructose consumption rates have increased dramatically such that fructose now constitutes $\sim 10 \%$ of daily energy intake (23), whereas $\mathrm{Ca}^{2+}$ intake by Americans has decreased markedly to levels below recommended $(7,55)$. Likewise, glucose constitutes about half of HFCS and, the table sugar sucrose is the end product of luminal starch digestion and can reach average luminal concentrations of $\sim 48 \mathrm{mM}$ that may be high enough as to affect $\mathrm{Ca}^{2+}$ transport (31). We have previously shown fructose concentrations from luminal fluids to average $\sim 25 \mathrm{mM}$ (43). These substantial sugar concentrations increase the importance of identifying mechanisms by which luminal sugars can acutely compromise $\mathrm{Ca}^{2+}$ transport.

Because intestinal fructose metabolism can markedly reduce intracellular ATP concentrations, we tested the hypothesis that fructose acutely reduces transcellular active $\mathrm{Ca}^{2+}$ transport in the small intestine and predicted that $\mathrm{Ca}^{2+}$ transport should be normal in GLUT5 ${ }^{-1-}$ and $\mathrm{KHK}^{-1-}$ mice that cannot absorb and metabolize, respectively, dietary fructose.

\section{MATERIALS AND METHODS}

Animal and experimental design. Male C57BL/6 wild-type mice weighing 13-15 g (4 wk old) were obtained from Taconic (Germantown, NY) and housed in the Research Animal Facility of the NJMS in a temperature-controlled room of $22-24^{\circ} \mathrm{C}$ with a $12-\mathrm{h}: 12-\mathrm{h}$ light/ dark cycle. Mice were fed on a regular laboratory nonpurified diet (Purina Mills, Richmond, IN) and had access to water ad libitum before the beginning of the experiment. Both $\mathrm{KHK}^{-1-}$ (lacking both ketohexokinase isoforms $\mathrm{A}$ and $\mathrm{C}$ ) and GLUT5 ${ }^{-1-}$ mice have the same background strain as wild-type. Generation of $\mathrm{KHK}^{-1-}(19)$ and GLUT5 $^{-1-}(73)$ are as described in detail previously. Intestines from
CaBP9k ${ }^{-1-}$ mice were a generous gift from Prof. Sylvia Christakos of the New Jersey Medical School. All of the procedures conducted in this study were approved by the Institutional Animal Care and Use Committee of NJMS.

In this study, all mice used for transport studies were chronically fed either a low- or normal- $\mathrm{Ca}^{2+}$ diet, and dietary carbohydrate content was similar in both diets. Thus 4-wk-old wild-type, $\mathrm{KHK}^{-/-}$, and GLUT5 ${ }^{-1-}$ mice were each divided into two groups and fed either with normal-Ca ${ }^{2+}\left(0.5 \% \mathrm{Ca}^{2+}\right.$ diet; D10122104 based on AIN-93M; Research Diets, New Brunswick, NJ) or low-Ca ${ }^{2+}$ diet $\left(0.02 \% \mathrm{Ca}^{2+}\right.$; D11040807) for $4 \mathrm{wk}$. Our proximate analysis confirmed these $\mathrm{Ca}^{2+}$ levels and also indicated that concentrations of phosphate and other electrolytes were the same in both diets. Active intestinal $\mathrm{Ca}^{2+}$ transport was determined using the everted gut sac assay described below, in the presence of various sugars added in the incubation medium. Tissue was also harvested, and RNA was isolated for quantification of gene expression by real-time PCR.

As we were comparing in some experiments the acute effects of different sugars on diet-inducible $\mathrm{Ca}^{2+}$ transport, these experiments only utilized mice fed a low- $\mathrm{Ca}^{2+}$ diet and thus exhibited high rates of $\mathrm{Ca}^{2+}$ transport. We first had to demonstrate that wild-type, GLUT5 ${ }^{-\prime-}$, and $\mathrm{KHK}^{-\prime-}$ mice were equally capable of upregulating $\mathrm{Ca}^{2+}$ transport when fed a low-Ca ${ }^{2+}$ diet. Breeding of $\mathrm{KHK}^{-1-}$ and of GLUT5 ${ }^{-1-}$ mice was completely unpredictable, and the sex ratio varied markedly between litters; thus whenever we were able to wean two same-age $\mathrm{KHK}^{-1-}$ or GLUT5 ${ }^{-1-}$ males, one would be fed a normal- $\mathrm{Ca}^{2+}$ and the other a low-Ca ${ }^{2+}$ diet for $4 \mathrm{wk}$, and then $\mathrm{Ca}^{2+}$ transport would be determined as described below. Because dietinducible, active $\mathrm{Ca}^{2+}$ transport is age dependent, we used agematched mice in all experiments.

When it was shown that upregulation by low- $\mathrm{Ca}^{2+}$ diet was the same in all three genotypes, we studied the acute effects of glucose and fructose on this inducible component of $\mathrm{Ca}^{2+}$ transport. Whenever we were able to wean two same-age $\mathrm{KHK}^{-1-}$ or GLUT5 ${ }^{-1-}$ males, both were fed low-Ca ${ }^{2+}$ diets, and, after $4 \mathrm{wk}, \mathrm{Ca}^{2+}$ transport was determined in the presence of glucose in one duodenal sac from one mouse and in the presence of fructose in another sac from another mouse.

In vitro intestinal $\mathrm{Ca}^{2+}$ transport. Mice were weighed and anesthetized by an i.p. injection of $2-4 \mathrm{ml} / \mathrm{kg}$ body wt of a mixture of ketamine $(20 \mathrm{mg} / \mathrm{ml})$ and xylazine $(2.5 \mathrm{mg} / \mathrm{ml})$. Intestinal $\mathrm{Ca}^{2+}$ transport was determined using the classical everted gut sac method, following protocols validated using TRPV6/CaBP-null (double deletion) mice by Benn et al. (5) and described in detail by others $(6,8)$, who showed that the everted gut sac assay selectively measures active intestinal $\mathrm{Ca}^{2+}$ transport because the $\mathrm{Ca}^{2+}$ transport is against a concentration gradient, occurs at low concentrations of $\mathrm{Ca}^{2+}$, and is saturable. In fact, many kinetic characteristics of $\mathrm{Ca}^{2+}$ transport determined by the everted sac method are in many respects similar to those of observed in vivo $(26,59)$. We also showed that $\mathrm{Ca}^{2+}$ transport in uneverted compared with everted sacs is low and likely paracellular (25). We used the everted sac as many studies on $\mathrm{Ca}^{2+}$ transport have used this method. Only one everted sac from the duodenum could be taken per animal. We used the duodenum because 1) active, diet-inducible $\mathrm{Ca}^{2+}$ transport decreases markedly in more distal intestinal regions and 2) fructose and glucose absorption are greater in the duodenum and proximal jejunum than in more distal regions $(6,12,25,28)$.

The first $7 \mathrm{~cm}$ of the proximal duodenum was removed, rinsed with ice-cold $\mathrm{Ca}^{2+}$ transport buffer [(in $\left.\mathrm{mM}\right) 125 \mathrm{NaCl}, 11.3 \mathrm{HEPES}$, and $0.25 \mathrm{CaCl}_{2}, \mathrm{pH}=7.4$, osmolality $=280 \mathrm{mOsm} / \mathrm{kg}$ ], and then slowly everted by rolling the segment along the stainless steel rod. The everted intestinal segment was filled with $500 \mu \mathrm{l}$ of $\mathrm{Ca}^{2+}$ transport buffer with $10 \mathrm{mM}$ glucose, fructose, or sugar analogs that was trapped inside by tying threads on both ends. The sugar concentration of $10 \mathrm{mM}$ was based on our previous findings on average total intestinal luminal glucose and fructose $(0.4-26 \mathrm{mM})$ concentrations 
that can reach up to $48 \mathrm{mM}$ in the duodenum during peak feeding times $(31,43)$. The sacs were incubated in test tubes with exactly the same incubation buffer as that inside the sac, plus ${ }^{45} \mathrm{CaCl}_{2}(40,000$ $\mathrm{cpm} / \mathrm{ml}$ ). After $1 \mathrm{~h}$, the intact sacs were removed, and $50 \mu \mathrm{l}$ of serosal fluid were collected and then analyzed for ${ }^{45} \mathrm{Ca}^{2+}$ in Ecolume (a premixed liquid scintillation cocktail, MP Biomedical, Solon, $\mathrm{OH}$ ), using a liquid scintillation counter (Beckman LS6500; Beckman, Fullerton, CA). The active accumulation of ${ }^{45} \mathrm{Ca}^{2+}$ inside the sac was expressed as a ratio of the final concentration of ${ }^{45} \mathrm{Ca}^{2+}$ inside (serosal compartment) and ${ }^{45} \mathrm{Ca}^{2+}$ outside (mucosal compartment). After the removal $50 \mu \mathrm{l}$ from the serosal compartment for counting, excess fluid was drained from the sac, and the tissue was blotted dry, weighed, and digested using Solvable (PerkinElmer, Waltham, MA) at $37^{\circ} \mathrm{C}$ for 24 $\mathrm{h}$ before ${ }^{45} \mathrm{Ca}^{2+}$ determination. ${ }^{45} \mathrm{Ca}^{2+}$ accumulated in the tissue was divided by the weight of the empty sac.

In some studies, the ratio of ${ }^{45} \mathrm{Ca}_{\text {in }} /{ }^{45} \mathrm{Ca}_{\text {out }}$ in mice fed a low- $\mathrm{Ca}^{2+}$ diet was expressed relative to those fed normal $\mathrm{Ca}^{2+}$ for experiments done the same day. This was necessary because breeding of $\mathrm{KHK}^{-1-}$ and GLUT5 ${ }^{-1-}$ mice was not predictable, and thus experiments could not be done with wild-type mice. In turn, $\mathrm{Ca}^{2+}$ transport in sacs from mice fed the normal- $\mathrm{Ca}^{2+}$ diet was normalized to average values from multiple experiments (see Fig. 3). Once we demonstrated that a low- $\mathrm{Ca}^{2+}$ diet induced $\mathrm{Ca}^{2+}$ transport in intestines from wild-type, $\mathrm{CaBP} \mathrm{k}^{-\prime-}$, and GLUT5 ${ }^{-\prime-}$ mice, we then used mice fed only low $\mathrm{Ca}^{2+}$ to determine the effect of acute glucose or fructose incubation on the diet-inducible component of $\mathrm{Ca}^{2+}$ transport (see Fig. 6). Here, the ratio of ${ }^{45} \mathrm{Ca}_{\text {in }} /{ }^{45} \mathrm{Ca}_{\text {out }}$ in intestines incubated with fructose was expressed relative to those incubated with glucose for experiments done the same day. $\mathrm{Ca}^{2+}$ transport in sacs incubated with glucose was normalized to average values from multiple experiments (see Fig. 6). Regarding experiments that used only wild-type mice, no normalization was made, and absolute values are presented, as $\mathrm{Ca}^{2+}$ transport was determined in all treatments simultaneously.

ATP measurement in the intestinal mucosa. Intracellular ATP concentration was determined using a rapid bioluminescence ATP assay kit according to the manufacturer's instructions (EnzyLight ATP assay kit; BioAssay Systems, Hayward, CA). With the use of instruments kept ice-cold in the freezer and ice-cold solutions, $\sim 20 \mathrm{~cm}$ of the proximal small intestine was flushed with ice-cold PBS ( $\mathrm{pH} 7.4)$. The mucosa was quickly scraped on a glass slide on ice, suspended in ice-cold HEPES-buffered balanced salt solution (in mM, 25 HEPES, $121 \mathrm{NaCl}, 5 \mathrm{NaHCO}_{3}, 4.7 \mathrm{KCl}, 1.2 \mathrm{MgSO}_{4} \cdot 7 \mathrm{H}_{2} \mathrm{O}, 1.1$ phosphate, and $2 \mathrm{CaCl}_{2}, \mathrm{pH} 7.4$ ), and mixed by gentle inversions of test tubes encased in ice. A $125-\mu l$ aliquot was then pipetted and incubated in $125 \mu l$ of sugar solution (also dissolved in ice-cold HEPES-buffered balanced salt solution) as instructed (final concentration $=5.5 \mathrm{mM}$ ) for $5 \mathrm{~min}$ at $37^{\circ} \mathrm{C}$. Thus the concentrations of the other components were not changed after 1:1 dilution.

After incubation, the entire sample was immediately transferred into $250 \mu \mathrm{l}$ of $0.2 \mathrm{M}$ trichloroacetic acid solution and homogenized by a tissue grinder (IKA Ultra-Turrax T25 Basic Homogenizer; IKA Works, Wilmington, NC) on ice. The supernatant was separated by centrifugation at $12,000 \mathrm{~g}$ for $5 \mathrm{~min}$ at $4^{\circ} \mathrm{C}$. Two $50-\mu \mathrm{l}$ aliquots of samples were kept in $-80^{\circ} \mathrm{C}$ until further analyses for protein levels. To measure the ATP level, the supernatant was first buffered with 25 $\mu \mathrm{l}$ of $0.2 \mathrm{M} \mathrm{NaOH}$ solution, and then $10 \mu \mathrm{l}$ of sample was transferred in duplicate into 96-well white opaque plates (PerkinElmer Life Sciences). Each well contained $90 \mu \mathrm{l}$ of a reconstituting reagent containing a mixture of assay buffer, $D$-luciferin, and luciferase enzyme at a ratio of 95:1:1 ( $\mathrm{vol} / \mathrm{vol} / \mathrm{vol})$. Luminescence was read against blanks (buffer without sample) using an automated microplate reader (Multilabel HTS Counter; VICTOR, Wallac, Finland) (67). Protein levels were quantified by BCA protein assay kit (Pierce ThermoFisher Scientific, Rockford, IL), using bovine serum albumin as a protein standard. ATP concentration was normalized to per milligram of protein.

Total mRNA extraction, DNase treatment, and RT reaction. Total RNA was extracted using a commercially available TRIZOL reagent (Invitrogen, Carlsbad, CA). To hydrolyze contaminating DNA in RNA preparation, $100 \mu \mathrm{g}$ RNA was combined with $10 \mu \mathrm{l}$ DNase I and $70 \mu \mathrm{l}$ RDD buffer (RNeasy Mini Kit; Qiagen, Valencia, CA) in a final volume of $100 \mu \mathrm{l}$. The cDNA was generated from $5 \mu \mathrm{g}$ DNase-treated RNA using 200 U of SuperScript III RNase H Reverse Transcriptase and oligo (dT) 20 (Invitrogen) in a total volume of $20 \mu \mathrm{l}$.

Gene expression by real-time PCR. Real-time PCR was performed using Mx3000P (Stratagene Real-Time PCR System, La Jolla, CA), as described previously (21). Primers were designed using Roche primer design software (http://www.roche-applied-science.com) and were purchased from Integrated DNA Technologies (IDT, Coralville, IA) (Table 1). The relative ratio of expression levels of target genes was calculated as described previously (63). Gene expression was relative to elongation factor- $1 \alpha$ gene, whose expression was previously found to be independent of $\mathrm{Ca}^{2+}$ level in the diet and of age of the mice.

Immunohistochemistry. Two centimeters of mouse duodenum were excised and immediately fixed in fresh $10 \%$ paraformaldehyde in PBS $(\mathrm{pH}=7.35)$ overnight at room temperature $\left(25^{\circ} \mathrm{C}\right)$. After fixation,

Table 1. Primer sequences of genes whose expression level had been measured by real-time PCR

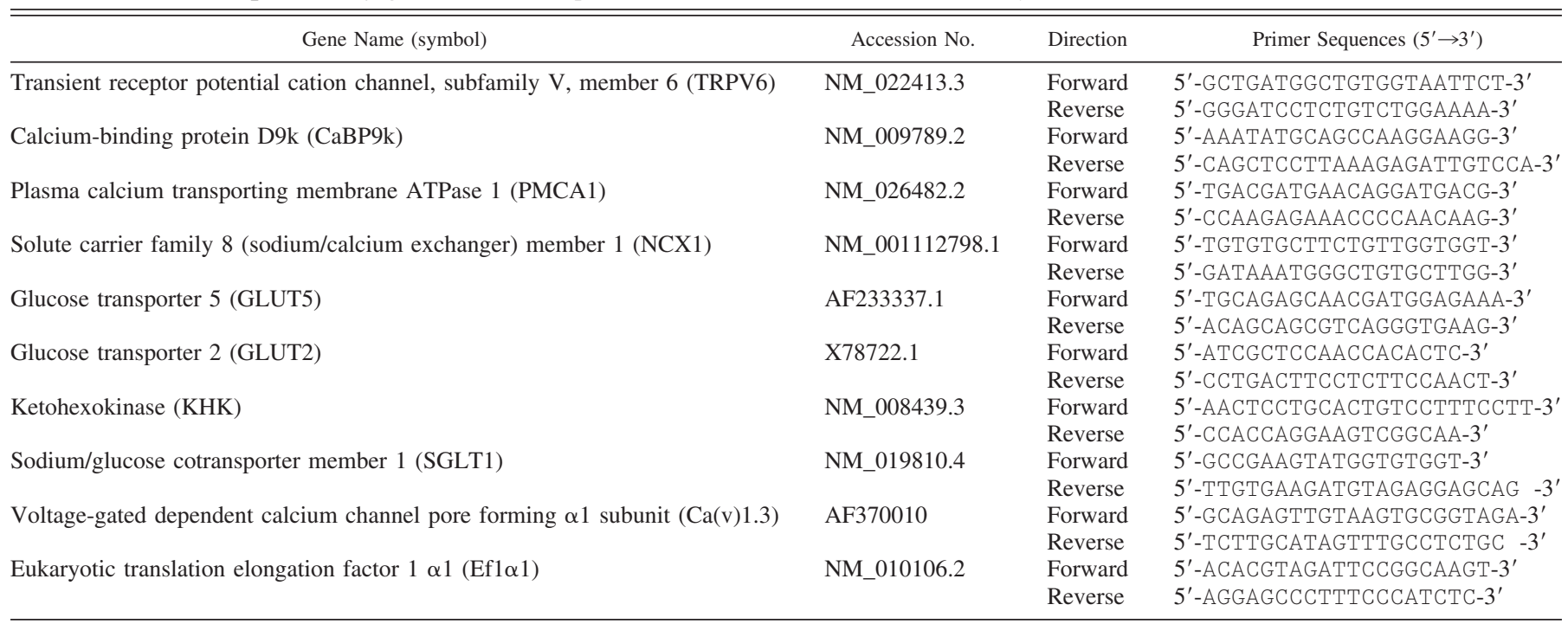


tissue samples were embedded in paraffin, then sectioned $(\sim 5 \mu \mathrm{m})$, deparaffinized, and rehydrated as previously described (22). Antigen unmasking was processed in $10 \mathrm{mM}$ sodium citrate buffer ( $\mathrm{pH}$ 6.0) solution in heat-induced antigen retrieval programmed pressure cooker (2100-Retriever; ProteoGenix, Schiltigheim, France). Slices were washed in sterile water and then blocked with $1 \%$ normal goat serum for $1 \mathrm{~h}$ at room temperature. Tissue sections were incubated in primary antibody in dark humidified chamber; chicken anti-KHK (1:200; Sigma-Aldrich, St. Louis, MO), and rabbit anti-Calbindin D-9k (1:1,000; Swant Swiss Antibodies, Bellinzona, Switzerland) in diluted in $1 \%$ normal goat serum overnight at $4{ }^{\circ} \mathrm{C}$. The section was then washed in PBS three times at $10 \mathrm{~min}$ each. Fluorochrome-labeled secondary antibodies [DyLight 488-conjugated AffiniPure donkey anti-chicken IgG (1:400; Jackson ImmunoResearch, West Grove, PA) for $\mathrm{KHK}$ and $\mathrm{Cy}^{\mathrm{TM}} 3$ goat anti-rabbit $\mathrm{IgG}$ (Chemicon International, Temecula, CA) for CaBP9k (1:200)] were applied for $1 \mathrm{~h}$ at room temperature. After incubation, tissues were washed again in PBS and mounted with fluorescent mounting medium (Dako North America, Carpenteria, CA). The stained sections were examined at $\times 20$ with a laser scanning confocal microscope (Nikon Eclipse Ti; NIS-Elements AR 4.11.00 program). All images of sections being compared were obtained with the same settings of the microscope. Nonspecific staining with secondary antibodies alone was consistently negligible. The KHK and $\mathrm{CaBP} 9 \mathrm{k}$ antibodies did not stain sections from $\mathrm{KHK}^{-1-}$ and $\mathrm{CaBP}^{-1-}$ mice, respectively.

Statistical analyses. Data are presented as means \pm SE. A two-way ANOVA analyzed the effects of genotype and diet or of genotype and incubation solution. When a two-way ANOVA could not be used, a one-way ANOVA was utilized to determine the difference among groups with different treatments. If there was a significant difference, Fisher's paired least significant difference test was used (STATVIEW; Abacus Concepts, Piscataway, NJ) to determine differences among means. Differences were considered significant at $P<$ 0.05. Graphs were plotted by GraphPad Prism 5.0 (GraphPad Software, San Diego, CA).

\section{RESULTS}

Fructose decreases intracellular ATP concentration in wildtype but not in $\mathrm{KHK}^{-/-}$mice. In preliminary work, we determined ATP concentrations in mucosal homogenates incubated in fructose and glucose for up to $20 \mathrm{~min}$ (not shown) and found that the rate of ATP reduction was linear for $\leq 5 \mathrm{~min}$, a time course used in the next series of experiments. Initial ATP concentrations were $47.1 \pm 1.4 \mathrm{nmol} / \mathrm{mg}$ of protein and did not differ significantly among glucose- and fructose-incubated mucosal homogenates from wild-type and $\mathrm{KHK}^{-/-}$mice. After incubation of mucosal homogenates with glucose or fructose solutions, ATP concentrations decreased from initial at a rate of $\sim 14 \% / \mathrm{min}$ in glucose-incubated mucosal homogenates of wild-type mice (Fig. 1A). Fructose incubation further reduced ATP levels, so the concentration remaining was only $7.9 \pm$ $0.32 \%$ of initial or about half of that remaining in glucoseincubated mucosa. By two-way ANOVA, the effects of KHK deletion and of sugar incubation on ATP levels were highly significant ( $P=0.005$ and 0.02 , respectively). The interaction between genotype and sugar treatments was also significant $(P=0.0316)$, suggesting that fructose-induced ATP reduction depended on genotype. The difference between glucose and fructose effects on ATP concentrations in wild-type mice was highly significant $(P<0.001)$. In contrast, in $\mathrm{KHK}^{-/-}$mice, the amount of ATP left was similar between fructose- and glucose-incubated mucosa. Increasing the incubation time further reduced ATP levels, but the fructose-incubated mucosa
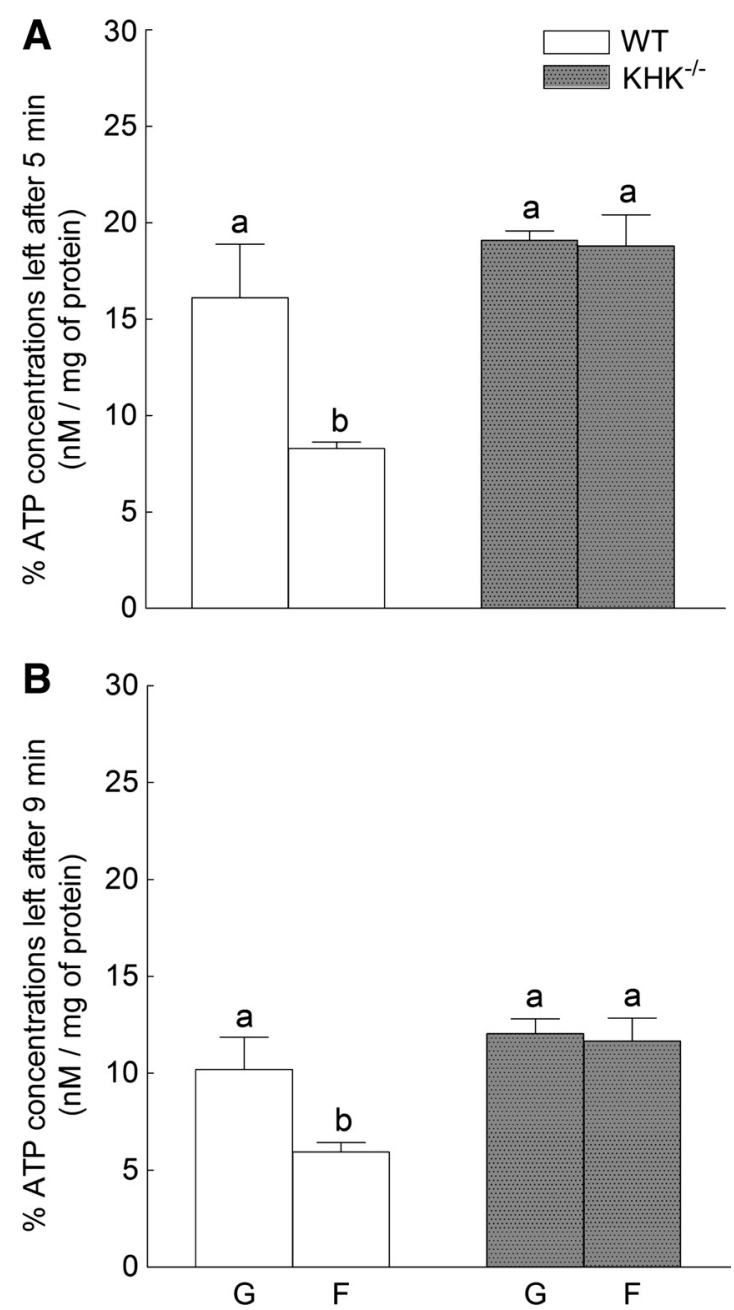

Fig. 1. Changes in intracellular ATP levels after incubation with $5.5 \mathrm{mM}$ glucose $(\mathrm{G})$ or fructose $(\mathrm{F})$. Intestinal mucosa from wild-type (WT) and ketohexokinase $(\mathrm{KHK})^{-1-}$ mice fed commercial chow were scraped then placed on glass slides on ice, homogenized in ice, and then incubated in glucose or fructose solutions for 5 and 9 min at $37^{\circ} \mathrm{C}$ following kit manufacturer instructions. Intracellular ATP concentrations were determined by a rapid bioluminescent method. Values are means $\pm \mathrm{SE}(n=3-4)$. Different letters denote significant $(P<0.05)$ differences. KHK-mediated fructose metabolism reduces ATP concentrations in intestinal mucosal homogenates.

from wild-type mice still had the greatest decrease (Fig. 1B). By two-way ANOVA, the effects of KHK deletion and of fructose incubation on ATP levels were still significant at 9 $\min (P=0.003$ and 0.05 , respectively). The interaction between genotype and sugar solution was not significant $(P=$ $0.10)$ although a post hoc $t$-test between glucose and fructose effects in wild-type mice was highly significant $(P<0.01)$. Although this finding merely confirms earlier work indicating marked reductions in enterocyte ATP levels with fructose (33, $38,48,54)$, it does show for the first time that KHK may be the major reason for this marked decrease in ATP levels in intestinal mucosa exposed to fructose.

CaBP9k and $\mathrm{KHK}$ are expressed in the small intestine. We have previously shown GLUT5 protein (25) and mRNA (42) to be expressed in enterocytes lining the villi, especially near the tip. Before testing our hypothesis, we wanted to demonstrate that $\mathrm{CaBP} 9 \mathrm{k}$ is found in cells where KHK-mediated fructose metabolism occurs. KHK is clearly found in enterocytes along 
the villus axis of the duodenum (Fig. $2 A$ ) as well as that of the ileum (Fig. 2B). The KHK antibody is specific, as indicated by the absence of immunofluorescence in wild-type mice probed with secondary antibody alone, and in $\mathrm{KHK}^{-1-}$ mice probed with both primary and secondary antibodies (Fig. 2E). CaBP9k distribution is similar to that of KHK in wild-type mice fed low- $\mathrm{Ca}^{2+}$ diets (Fig. 2A). However, in wild-type mice fed a normal- $\mathrm{Ca}^{2+}$ diet (Fig. $2 C$ ), there was a marked reduction in $\mathrm{CaBP} 9 \mathrm{k}$ immunofluorescence, and $\mathrm{CaBP} 9 \mathrm{k}$ was expressed in only a few cells (see merged panel). In mice fed low $\mathrm{Ca}^{2+}$, there seems to be a regional gradient of $\mathrm{CaBP} 9 \mathrm{k}$ expression as levels decrease in the ileum (compare Fig. $2 A$, left with Fig. $2 B$, left).

CaBP9k distribution was also heterogeneous and seemingly punctuate, with some cells expressing more immunoreactive protein than others, along the intestinal villus axis of GLUT5 ${ }^{-1-}$ (not shown) and $\mathrm{KHK}^{-1-}$ mice (Fig. $2 F$, left) as well as of rats (Fig. $2 F$, right) fed normal- $\mathrm{Ca}^{2+}$ diets. The $\mathrm{CaBP} 9 \mathrm{k}$ antibody has also been shown to be highly specific as indicated by negative controls of intestinal sections from wild-type (probed with secondary antibody only) and $\mathrm{CaBP}^{-1-}$ (probed with both primary and secondary antibodies) mice (Fig. 2D).

Low-Ca ${ }^{2+}$ diets increased $\mathrm{Ca}^{2+}$ transport as well as TRPV6 and CaBP9k expression. When fed a low-Ca ${ }^{2+}$ diet, mice of all three genotypes clearly exhibited large adaptive increases of $60-100 \%$ in transepithelial (ratios of ${ }^{45} \mathrm{Ca}_{\text {in }} /{ }^{45} \mathrm{Ca}_{\text {out }}$; Fig. $3 A$ ) and in transmembrane (amounts of ${ }^{45} \mathrm{Ca}^{2+}$ accumulated in tissues; Fig. $3 B$ ) transport of $0.25 \mathrm{mM} \mathrm{Ca}^{2+}$. This adaptive increase in transepithelial and transmembrane $\mathrm{Ca}^{2+}$ transport induced by $\mathrm{Ca}^{2+}$-deficient diets has been shown to be active, $1,25(\mathrm{OH})_{2} \mathrm{D}_{3}$ dependent, and mediated mostly by TRPV6 and CaBP9k $(5,6,8,24,25)$.

The absolute ratios of ${ }^{45} \mathrm{Ca}_{\text {in }} /{ }^{45} \mathrm{Ca}_{\text {out }}$ in mice fed normal $\mathrm{Ca}^{2+}$ were $0.46 \pm 0.04$ for wild-type, $0.51 \pm 0.05$ for $\mathrm{GLUT5}^{-/-}$, and $0.47 \pm 0.03$ for $\mathrm{KHK}^{-1-}$ (Fig. 3A). The amounts of ${ }^{45} \mathrm{Ca}^{2+}$ accumulated in tissues were $39.9 \pm 3.2$ for wild-type, $38.0 \pm 2.8$ for GLUT5 $^{-1-}$, and $43.8 \pm 2.4 \times 10^{3}$ $\mathrm{cpm} / \mathrm{g}$ tissue for $\mathrm{KHK}^{-1-}$ mice (Fig. $3 B$ ). Because experiments could not be conducted at the same time across genotype, $\mathrm{Ca}^{2+}$ transport in sacs from mice fed low $\mathrm{Ca}^{2+}$ were subsequently normalized to those in sacs from mice fed normal $\mathrm{Ca}^{2+}$ levels for each genotype. When analyzed by two-way ANOVA, genotype had no effect on normalized transepithelial $(P=$ $0.17)$ and transmembrane $(P=0.62) \mathrm{Ca}^{2+}$ transport. In contrast, diet had a dramatic effect $(P<0.0001$ for Fig. 3, $A$ and $B)$, but there was no interaction between genotype and $\operatorname{diet}(P$ $\geq 0.28$ ).

The increases in $\mathrm{Ca}^{2+}$ transport were paralleled by dramatic 30- to 40-fold increases in mRNA expression of known major players of $\mathrm{Ca}^{2+}$ transport (40). Relative TRPV6 and CaBP9k mRNA expression were significantly upregulated by diet $(P<$ 0.0001 by two-way ANOVA) in intestines of wild-type,

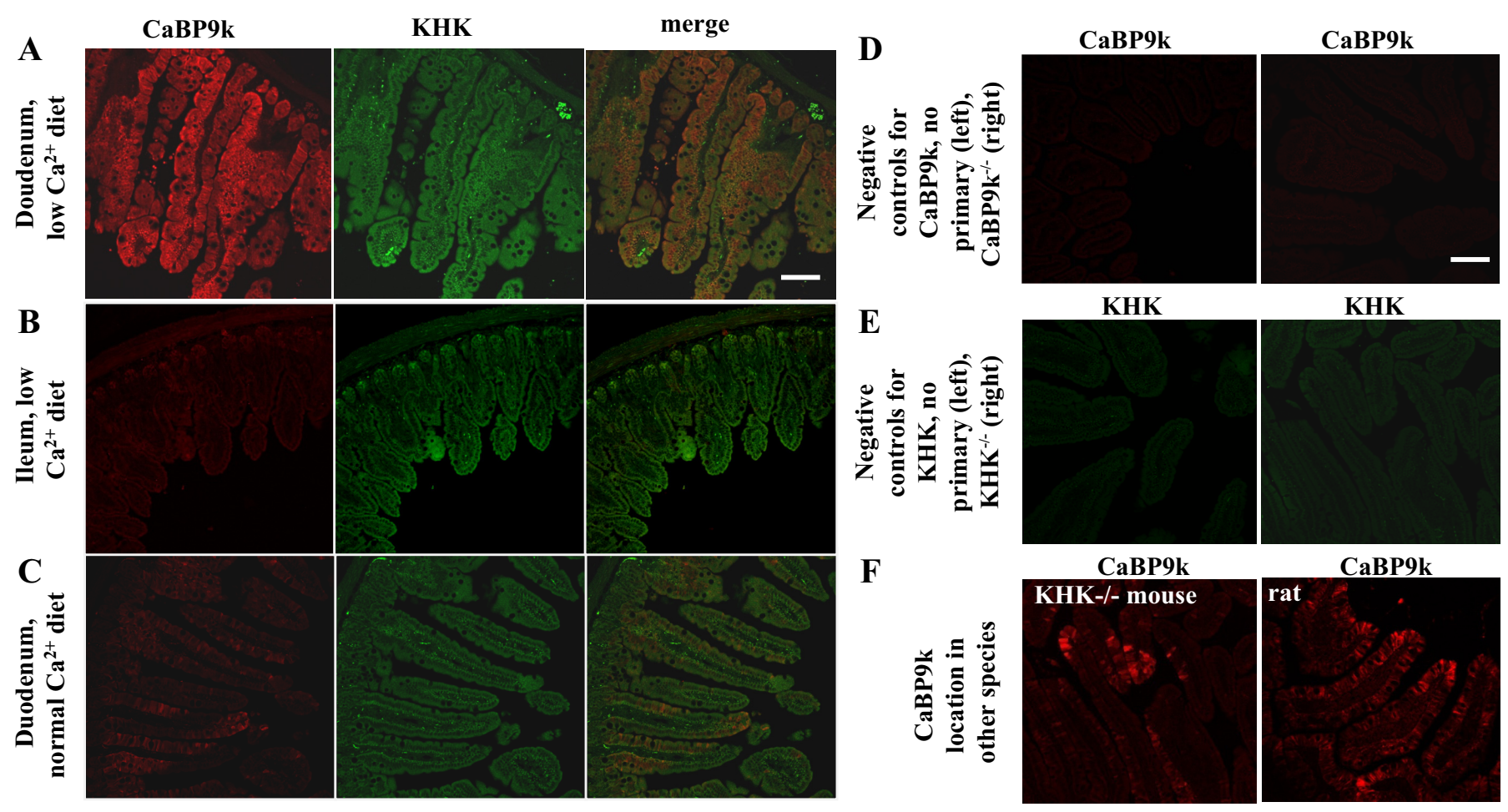

Fig. 2. Location of $\mathrm{Ca}^{2+}$-binding protein $\mathrm{D}_{9} \mathrm{~K}(\mathrm{CaBP} 9 \mathrm{k}$ ) and $\mathrm{KHK}$ along the villus. A: distribution of $\mathrm{CaBP} 9 \mathrm{k}$ (left, red) and $\mathrm{KHK}$ (middle, green) along the entire duodenal villus of wild-type mice fed low $\mathrm{Ca}^{2+}$ levels. The merged panel (right) shows that the distribution of CaBP9k overlaps with that of KHK in most cells lining the villi of mice fed low-Ca ${ }^{2+}$ diets. White bar in $A=100 \mu \mathrm{m}$, images taken at $\times 20$ magnification. Distribution of CaBP9k and KHK in the ileum $(B)$ of wild-type mice fed low $\mathrm{Ca}^{2+}$ and in the duodenum $(C)$ of wild-type mice fed normal $\mathrm{Ca}^{2+}$ levels. KHK distribution was not affected by dietary Ca ${ }^{2+}$ levels. CaBP9k expression along the intestinal crypt-villus axis of mice fed normal $\mathrm{Ca}^{2+}$ seems depleted and heterogeneous as indicated in the merged panel (right). $D$ : negative control sections for $\mathrm{CaBP} 9 \mathrm{k}$, from wild-type mice probed with secondary antibody only (left) and from CaBP9k ${ }^{-1-}$ mice probed with primary and secondary antibody. White bars in $D$ and $E=100 \mu \mathrm{m}$, magnification $=\times 20$. E: negative control sections for KHK, from wild-type mice probed with secondary antibody only (left) and from $\mathrm{KHK}^{-1-}$ mice probed with primary and secondary antibody. Results indicate highly specific antibodies. $F$ : heterogeneous,

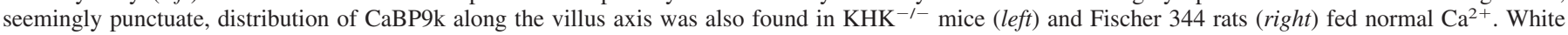
bar $=100 \mu \mathrm{m}$, image taken at $\times 20$. 

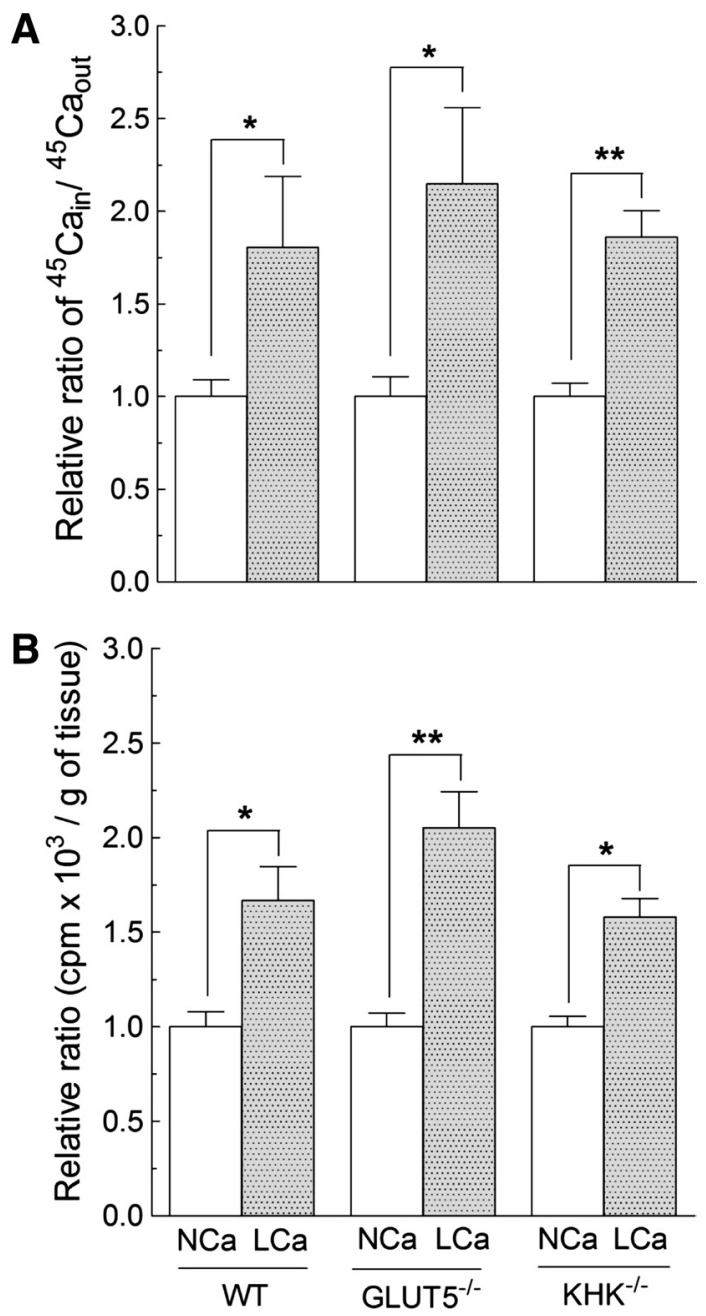

Fig. 3. Increased rates of $\mathrm{Ca}^{2+}$ transport after consumption of a low- $\mathrm{Ca}^{2+}$ diet for 4 wk. Mice were randomly divided into 2 groups then fed with normal$(\mathrm{NCa})$ or low- $\mathrm{Ca}^{2+}(\mathrm{LCa})$ diets. Because production of transgenic mice is unpredictable, $0.25 \mathrm{mM} \mathrm{Ca}^{2+}$ transport had to be determined at different times for wild-type, glucose transporter 5 (GLUT5) ${ }^{-1-}$, and $\mathrm{KHK}^{-1-}$ mice. Thus uptake in low $\mathrm{Ca}^{2+}$ was normalized to that of normal $\mathrm{Ca}^{2+}$ for each genotype. The composition of the solution outside the everted sac is exactly the same as that inside except tracer ${ }^{45} \mathrm{Ca}^{2+}$ was added to luminal side (outside the everted sac). All sacs were incubated with $10 \mathrm{mM}$ fructose. A: relative ratios of tracer concentration inside/outside the sacs were clearly much greater in wild-type, GLUT5 ${ }^{-1-}$, and $\mathrm{KHK}^{-1-}$ mice fed low $\mathrm{Ca}^{2+} . B$ : steady-state tissue ${ }^{45} \mathrm{Ca}^{2+}$ accumulation was also much greater in all mice fed low $\mathrm{Ca}^{2+}$. Bars are means $\pm \mathrm{SE} ; * * P<0.01 ; * P<0.05, n=5-6$.

GLUT5 $^{-1-}$, and $\mathrm{KHK}^{-1-}$ mice fed low-Ca ${ }^{2+}$ diets (Fig. 4, A and $B$ ). Protein levels of CaBP9k also seem to increase in wild-type mice fed low $\mathrm{Ca}^{2+}$ (compare Fig. 2, $A$ and $C$ ). Genotype had no significant effect $(P \geq 0.06)$ on TRPV6 as well as CaBP9k expression, and there was no interaction between diet and genotype $(P \geq 0.09)$. PMCA1b expression was independent of dietary $\mathrm{Ca}^{2+}$ in wild-type mice, but, surprisingly, PMCA1b mRNA level increased slightly $(\sim 1.7-$ fold) with low $\mathrm{Ca}^{2+}$ in GLUT5 ${ }^{-1-}$ and $\mathrm{KHK}^{-1-}$ groups (Fig. $4 C)$. The effects of diet $(P<0.001)$ and genotype $(P=0.02)$ were significant, but there was no interaction $(P=0.53)$. The only $\mathrm{Ca}^{2+}$ transporter whose intestinal expression did not change with diet $(P=0.80)$ in any mouse model $(P=0.12)$ was NCX1 (Fig. 4D), and there was no interaction between these two factors $(P=0.19)$. Dietary $\mathrm{Ca}^{2+}$ had no effect on intestinal expression of GLUT5, GLUT2, and KHK involved in fructose transport and metabolism and of SGLT1 involved in active glucose transport (Fig. 4, $E-H$ ) (by two-way ANOVA, $P \geq 0.26$ ), and there was also no interaction between dietary $\mathrm{Ca}^{2+}$ and genotype $(P \geq 0.48)$. Because GLUT5 ${ }^{-1-}$ mice did not express GLUT5 mRNA, and $\mathrm{KHK}^{-1-}$ mice did not have KHK mRNA, the effect of genotype was highly significant $(P<$ 0.0001 ) on GLUT5 and KHK expression (Fig. 4, $E$ and $G$ ) but was insignificant on GLUT2 and SGLT1 expression $(P>0.30)$ (Fig. 4, $F$ and $H$ ).

The L-type $\mathrm{Ca}^{2+}$ channel $\mathrm{Ca}(\mathrm{v}) 1.3$ has been proposed to mediate active intestinal $\mathrm{Ca}^{2+}$ transport in combination with TRPV6 $(20,46)$, particularly because active $\mathrm{Ca}^{2+}$ transport is normal in $\mathrm{TRPV6}^{-1-}$ mice (5). However, expression of $\mathrm{Ca}(\mathrm{v}) 1.3$ in enterocytes is $\sim 20$ - to 30 -fold less than TRPV6 (data not shown), and $\mathrm{Ca}(\mathrm{v}) 1.3$ levels did not significantly respond to a low-Ca ${ }^{2+}$ diet (Fig. $\left.4 I\right)(P>0.10$ by two-way ANOVA) although there seemed to be a decrease in $\mathrm{Ca}(\mathrm{v}) 1.3$ expression in GLUT5 $^{-1-}$ mice. There was a significant effect of genotype $(P=0.003)$, but there was no interaction between dietary $\mathrm{Ca}^{2+}$ and genotype $(P=0.06)$. The low expression levels contributed to the large variation in estimates of $\mathrm{Ca}(\mathrm{v}) 1.3$ mRNA expression. It is not clear why $\mathrm{Ca}(\mathrm{v}) 1.3$ expression decreased in GLUT5 ${ }^{-1-}$ mice although this could be a random observation expected to occur 1 out of 20 times at $P<0.05$. Nonetheless, in wild-type, GLUT5 ${ }^{-1-}$, and $\mathrm{KHK}^{-1-}$ mice, the significant diet-induced increase in $\mathrm{Ca}^{2+}$ transport is clearly paralleled by large diet-induced increases in TRPV6 and $\mathrm{CaBP} 9 \mathrm{~K}$, but not in $\mathrm{Ca}(\mathrm{v}) 1.3$, mRNA expression.

Acute fructose effects on active $\mathrm{Ca}^{2+}$ transport. To test the hypothesis whether fructose decreases active $\mathrm{Ca}^{2+}$ transport, transepithelial $\mathrm{Ca}^{2+}$ transport was determined in everted intestinal sacs from wild-type mice incubated in solutions containing $10 \mathrm{mM}$ glucose (control) or fructose. There were significant treatment effects $(P<0.001$ by one-way ANOVA) on transepithelial (Fig. 5A) and transmembrane (Fig. 5B) $\mathrm{Ca}^{2+}$ transport. Transepithelial $\mathrm{Ca}^{2+}$ transport was low and similar between glucose- and fructose-incubated sacs obtained from mice fed a normal- $\mathrm{Ca}^{2+}$ diet: $0.35 \pm 0.02$ and $0.36 \pm 0.03$, respectively. $\mathrm{Ca}^{2+}$ transport increased markedly $(P<0.01)$ in all mice fed low- $\mathrm{Ca}^{2+}$ diets, regardless of incubation solution. This diet-inducible $\mathrm{Ca}^{2+}$ transport was much greater $(P<$ $0.01)$ in sacs incubated with fructose compared with those with glucose $(1.45 \pm 0.21$ and $0.93 \pm 0.08$, respectively). Thus the acute effect of fructose on $\mathrm{Ca}^{2+}$ transport depended on whether sacs came from mice fed normal- or low- $\mathrm{Ca}^{2+}$ diets.

L-glutamine at $1-12.8 \mathrm{mM}$ is often used as respiratory fuel to maintain enterocyte cultures $(17,56,58,74)$. Because fructose was expected to reduce ATP levels in intestinal cells and inhibit diet-induced $\mathrm{Ca}^{2+}$ transport, we predicted that addition of L-glutamine to the incubation media containing fructose would reverse the fructose effects. Glutamine was not added to sacs from mice fed normal $\mathrm{Ca}^{2+}$, as transepithelial $\mathrm{Ca}^{2+}$ transport there was low, and the acute addition of fructose had similar effects as glucose (control). Glucose- and glucose + glutamine-incubated sacs from mice fed low $\mathrm{Ca}^{2+}$ showed similar $(P>0.5)$ rates of active $\mathrm{Ca}^{2+}$ transport, which were both greater than those in sacs from mice fed normal $\mathrm{Ca}^{2+}$. Likewise, $\mathrm{Ca}^{2+}$ fluxes were also similar between sacs incubated with fructose alone and 

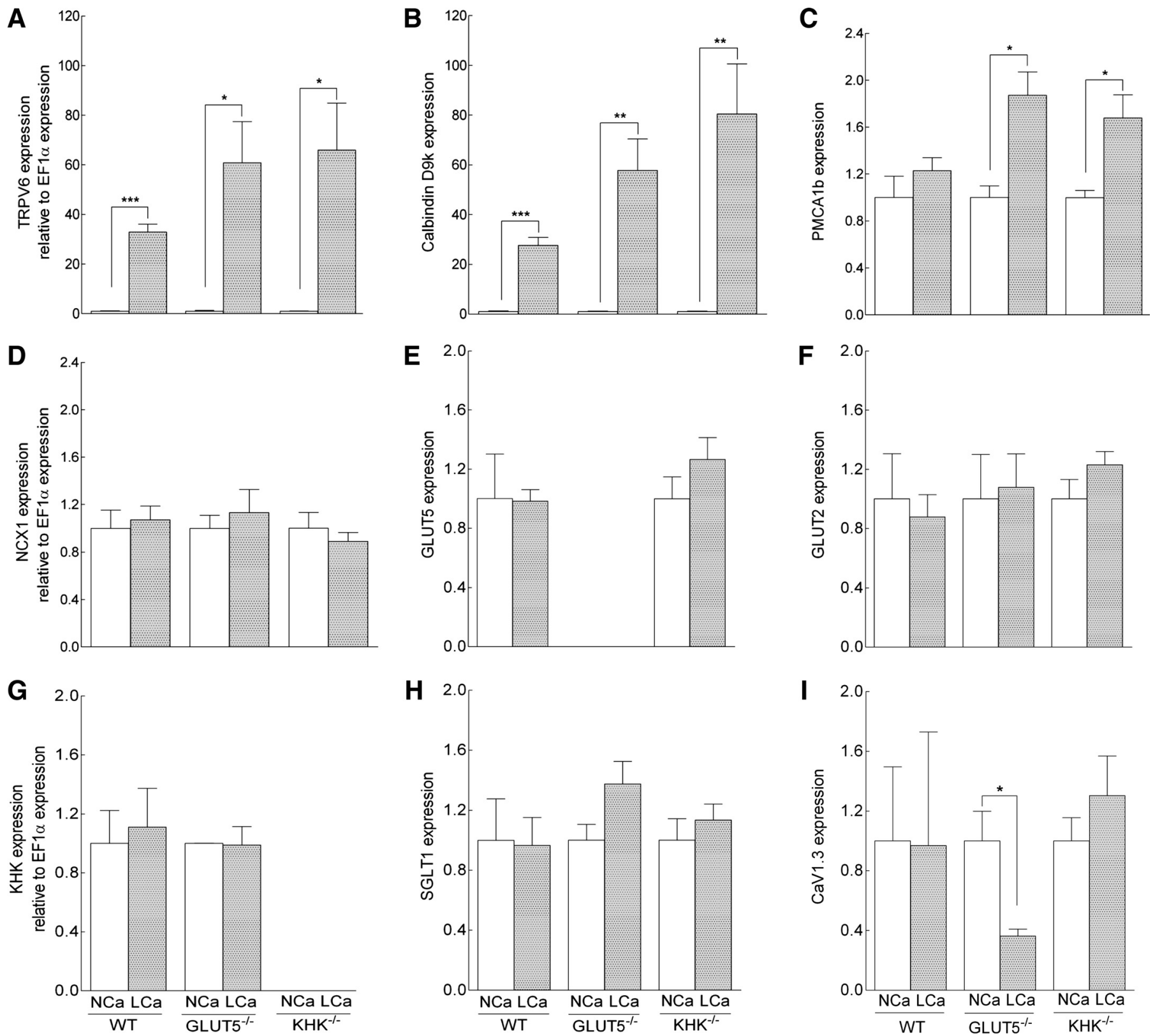

Fig. 4. The effect of low- $\mathrm{Ca}^{2+}$ diets on expression levels of genes involved in $\mathrm{Ca}^{2+}$ and fructose transport and metabolism. The mRNA expression of transient receptor potential vanilloid family calcium channel 6 (TRPV6) $(A), \mathrm{CaBP} 9 \mathrm{k}(B)$, plasma membrane $\mathrm{Ca}^{2+}-\mathrm{ATPase}$ isoform $1 \mathrm{~b}(\mathrm{PMCA} 1 \mathrm{~b})(C), \mathrm{Na}{ }^{+} / \mathrm{Ca}^{2+}$ exchanger isoform $1(\mathrm{NCX} 1)(D)$, GLUT5 $(E)$, GLUT2 $(F)$, KHK $(G)$, and sodium-glucose cotransporter 1 (SGLT1) $(H$, control) was examined by real-time PCR. Because recent work suggested it may also play a role in $\mathrm{Ca}^{2+}$ transport, expression of the L-type calcium channel $\mathrm{Ca}(\mathrm{v}) 1.3$ was also determined $(I)$. NCa and LCa represent normal- and low-Ca ${ }^{2+}$ diets, respectively. Bars are means $\pm \mathrm{SE}(n=5-6) . * P<0.05, * * P<0.01$, and $* * * P<0.001$ compared with NCa in the same genotype. In contrast to TRPV6 and CaBP9k mRNA expression, which increases by orders of magnitude when a Ca ${ }^{2+}$-deficient diet is consumed, $\mathrm{Ca}(\mathrm{v}) 1.3$ expression does not vary with levels of dietary $\mathrm{Ca}^{2+}$ and with genotype, except in $\mathrm{GLUT5}^{-1-}$ mice fed low $\mathrm{Ca}^{2+}$ when $\mathrm{Ca}(\mathrm{v}) 1.3$ expression decreased markedly. Moreover, relative mRNA abundance of $\mathrm{Ca}(\mathrm{v}) 1.3$ channels is $\sim 20$ to 30 -fold less compared with that of TRPV6, and the low expression contributed to the unusually large standard error. Bars are means \pm SE; $n=5-6$.

those with fructose+glutamine (Fig. 5A). The pattern of changes in steady-state accumulation of $\mathrm{Ca}^{2+}$ in the mucosal tissue (Fig. 5B) was similar to that of active transepithelial $\mathrm{Ca}^{2+}$ transport. In both cases, incubation of fructoseor fructose + glutamine-incubated sacs from mice fed low $\mathrm{Ca}^{2+}$ still resulted in $\mathrm{Ca}^{2+}$ transport (or accumulation) greater than that in glucose alone- or in glucose+glutamineincubated sacs. Thus addition of glutamine had no additional effect on diet-induced $\mathrm{Ca}^{2+}$ transport.
Deletion of KHK and GLUT5 did not affect diet-induced $\mathrm{Ca}^{2+}$ transport. $\mathrm{Ca}^{2+}$ uptake in the presence of fructose or glucose was determined only in mice fed low $\mathrm{Ca}^{2+}$, as Fig. 3 showed all three genotypes to adaptively increase $\mathrm{Ca}^{2+}$ transport in response to $\mathrm{Ca}^{2+}$ deficiency. Because the uptake experiment could not be conducted at the same time, uptake rates in fructose-incubated sacs had to be normalized to those of glucose-incubated sacs for each mouse model (Fig. 6, $A$ and $B$ ). The ratios of ${ }^{45} \mathrm{Ca}_{\text {in }} /{ }^{45} \mathrm{Ca}_{\text {out }}$ in glucose-incubated sacs used for 

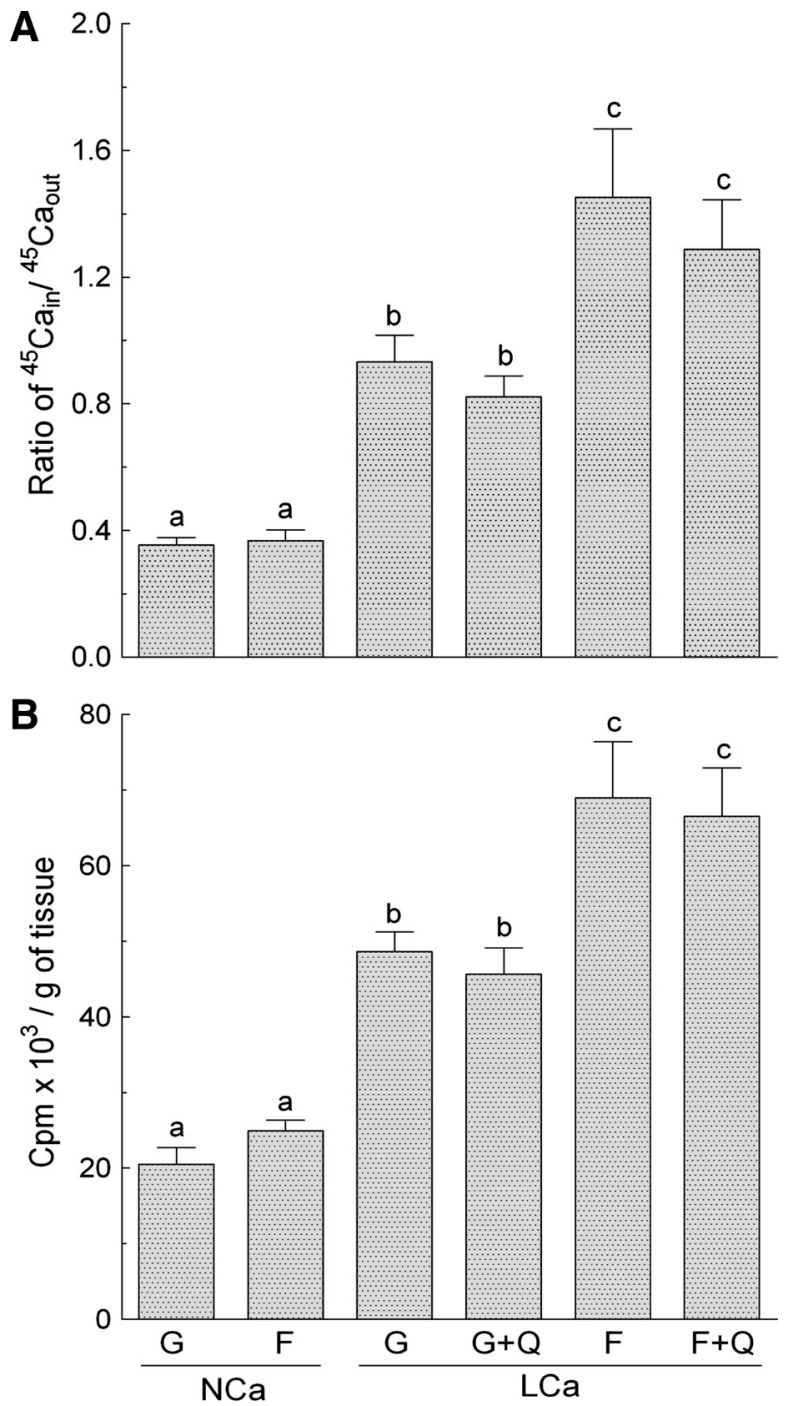

Fig. 5. The effect of sugars and L-glutamine on $0.25 \mathrm{mM} \mathrm{Ca}^{2+}$ transport $(A)$ and $\mathrm{Ca}^{2+}$ tissue uptake $(B)$. The everted sacs were incubated in $10 \mathrm{mM}$ glucose $(\mathrm{G})$ or fructose $(\mathrm{F})$ solution and were obtained from wild-type mice fed normal- $(\mathrm{NCa})$ or low-Ca ${ }^{2+}(\mathrm{LCa})$ diets for 4 wk. L-glutamine $(\mathrm{Q}, 10 \mathrm{mM})$ was added as enterocyte fuel in sacs obtained from mice fed low $\mathrm{Ca}^{2+}$. The composition of the solution outside the sac is exactly the same as that inside except tracer ${ }^{45} \mathrm{Ca}^{2+}$ was added to luminal side (outside the everted sac). Error bars represent means \pm SE $(n=4)$. Different letters denote significant $(P<$ $0.05)$ differences.

normalization were $0.58 \pm 0.02$ for wild-type, $0.52 \pm 0.05$ for $\mathrm{GLUT5}^{-\prime-}$, and $0.43 \pm 0.02$ for $\mathrm{KHK}^{-1-}$ for Fig. 6 A. The amounts of ${ }^{45} \mathrm{Ca}^{2+}$ accumulated in tissues incubated with glucose were $60.1 \pm 2.5$ for wild-type, $55.9 \pm 1.6$ for GLUT5 $^{-\prime-}$, and $53.1 \pm 11.4 \times 10^{3} \mathrm{cpm} / \mathrm{g}$ tissue for $\mathrm{KHK}^{-1-}$ for Fig. $6 B$. By two-way ANOVA, there was a highly significant effect of incubation solution on transepithelial $(P=$ $0.001)$ and transmembrane $(P=0.0002) \mathrm{Ca}^{2+}$ transport. In both measures of $\mathrm{Ca}^{2+}$ transport, genotype had no effect $(P \geq$ $0.18)$, and there was no interaction between incubation solution and genotype $(P \geq 0.70)$.

Consistent with data from Fig. 5, diet-induced active $\mathrm{Ca}^{2+}$ transport was greater in fructose- compared with that in glucose-incubated sacs in wild-type mice. In $\mathrm{KHK}^{-1-}$ mice, diet-induced $\mathrm{Ca}^{2+}$ transport was also greater in fructose- com- pared with glucose-incubated sacs. Interestingly, in GLUT5 ${ }^{-1-}$ mouse intestines that cannot absorb fructose (4) (C. Patel and R. Ferraris, unpublished observations), diet-induced active $\mathrm{Ca}^{2+}$ transport was still greater in fructose-incubated sacs. This finding suggests that fructose likely did not affect diet-induced $\mathrm{Ca}^{2+}$ transport because $\mathrm{Ca}^{2+}$ transport in the presence of fructose was similar among wild-type mice able to absorb and metabolize fructose, $\mathrm{KHK}^{-1-}$ mice unable to metabolize fructose (41), and GLUT5 ${ }^{-1-}$ mice unable to absorb fructose. The
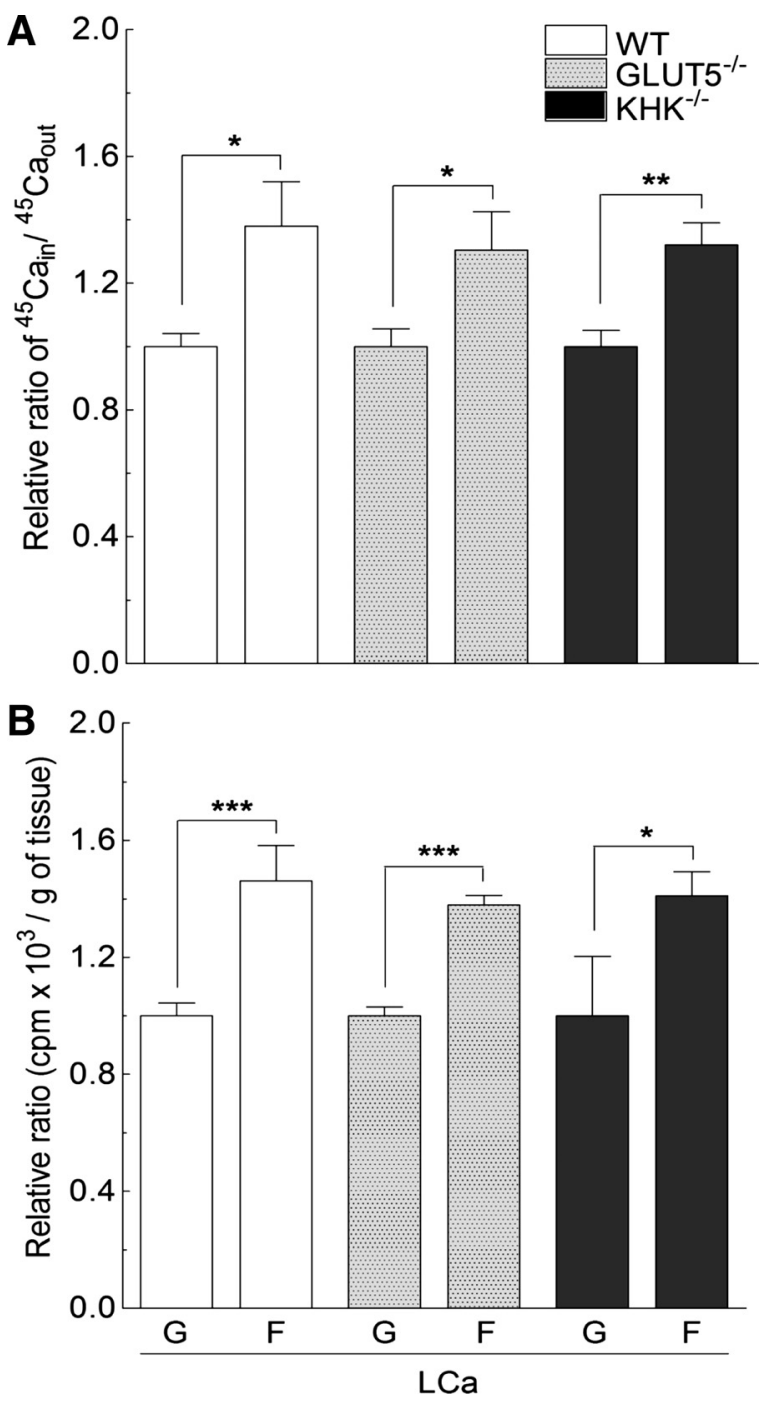

Fig. 6. The contributions of GLUT5 and KHK on sugar-modulated changes in active intestinal $\mathrm{Ca}^{2+}$ transepithelial transport $(A)$ and $\mathrm{Ca}^{2+}$ tissue uptake $(B)$. Wild-type, $\mathrm{KHK}^{-1-}$, and GLUT5 ${ }^{-1-}$ mice were fed with low-Ca ${ }^{2+} \operatorname{diet}(\mathrm{LCa})$, killed after $4 \mathrm{wk}$, and then $\mathrm{Ca}^{2+}$ fluxes were determined in everted sacs containing either $10 \mathrm{mM}$ glucose $(\mathrm{G})$ or fructose $(\mathrm{F})$. Because breeding of transgenic mice is unpredictable, $\mathrm{Ca}^{2+}$ transport was determined at different times for wild-type (WT), GLUT5 ${ }^{-1-}$, and $\mathrm{KHK}^{-1-}$ mice, and then $\mathrm{Ca}^{2+}$ uptake in fructose-incubated sacs was normalized to that in glucose-incubated, for each genotype. The composition of the solution outside the sac is exactly the same as that inside except tracer ${ }^{45} \mathrm{Ca}^{2+}$ was added to luminal side. Bars represent means $\pm \mathrm{SE}(n=5-6) . * P<0.05, * * P<0.01$, and $* * * P<0.001$ compared with glucose-incubated sacs obtained from the same genotype. In all mice, $\mathrm{Ca}^{2+}$ transport was greater in sacs from fructose-fed individuals, even in GLUT5 $^{-1-}$ mice, which do not absorb fructose, suggesting that perhaps the difference in $\mathrm{Ca}^{2+}$ transport consistently observed between glucose- and fructose-incubated sacs is due to a glucose-induced reduction of $\mathrm{Ca}^{2+}$ transport. 
substantial difference between diet-induced $\mathrm{Ca}^{2+}$ transport in the presence of fructose and that in glucose probably could result from a decrease of diet-induced active $\mathrm{Ca}^{2+}$ transport caused by glucose. If this prediction is correct, diet-induced $\mathrm{Ca}^{2+}$ transport in fructose-incubated sacs of wild-type mice should be similar to that of sacs incubated with nonabsorbed sugars like mannitol, and both should be greater than $\mathrm{Ca}^{2+}$ transport in glucose-incubated sacs.

Diet-induced $\mathrm{Ca}^{2+}$ transport may be acutely inhibited by glucose metabolism. In this experiment using wild-type mice, the role of metabolism was further evaluated by determining $\mathrm{Ca}^{2+}$ transport in the presence of the poorly metabolizable GLUT5 substrate 2-deoxy-D-glucose and the nonmetabolized SGLT1 substrate, 3-O-methylglucose, as well as the nonabsorbable sugar mannitol, which represented an osmotic control $(10,18)$. 2-Deoxy-D-glucose can be metabolized by hexokinase but not by other glycolytic enzymes, whereas 3-O-methylglucose cannot be metabolized at all.

In wild-type mice fed normal- $\mathrm{Ca}^{2+}$ diet, the $\mathrm{Ca}^{2+}$ fluxes were modest but similar $(P>0.5)$ in sacs incubated with glucose and fructose solutions. Active $\mathrm{Ca}^{2+}$ transport was induced $(P<0.001$ by one-way ANOVA) in five groups of mice fed low-Ca ${ }^{2+}$ diets. Diet-induced $\mathrm{Ca}^{2+}$ transport was always less $(P<0.01)$ when sacs were incubated with glucose compared with that of sacs with fructose (Fig. 7, $A$ and $B$ ). $\mathrm{Ca}^{2+}$ fluxes during incubation of sacs in 2-deoxy-D-glucose, 3-O-methylglucose, and mannitol solutions were similar to those in fructose and were each about $50 \%$ greater than those in glucose-incubated sacs from mice fed low $\mathrm{Ca}^{2+}$.

The similar effects of fructose, glucose analogs, and mannitol solutions on diet-induced active $\mathrm{Ca}^{2+}$ transport were confirmed in $\mathrm{KHK}^{-1-}$ mice. Transepithelial $\mathrm{Ca}^{2+}$ transport in sacs from $\mathrm{KHK}^{-1-}$ mice fed low-Ca ${ }^{2+}$ diets was $0.42 \pm 0.04$ when incubated with glucose and increased $(P<0.05$ by one-way ANOVA) to $0.59 \pm 0.06$ with fructose, $0.64 \pm 0.07$ with 2-deoxy-D-glucose, and $0.70 \pm 0.05$ with mannitol $(n=4-5)$.

\section{DISCUSSION}

The main findings in this study are that 1 ) fructose transport, fructose metabolism, and fructose-induced changes in the level of mucosal ATP have no acute effect on active, inducible intestinal $\mathrm{Ca}^{2+}$ transport mediated by TRPV6 and CaBP9k; 2) glucose metabolism appears to decrease this component of intestinal $\mathrm{Ca}^{2+}$ transport that is inducible by a low- $\mathrm{Ca}^{2+}$ diet; and 3) CaBP9k distribution may be expressed only in some intestinal cells in rodents consuming a normal- $\mathrm{Ca}^{2+}$ diet.

KHK and GLUT5 deletion does not affect adaptive increases in intestinal $\mathrm{Ca}^{2+}$ transport. When dietary $\mathrm{Ca}^{2+}$ concentration is nutritionally adequate, TRPV6 and CaBP9k expression is very low, suggesting that the modest $\mathrm{Ca}^{2+}$ transport exhibited by sacs from mice fed sufficient dietary $\mathrm{Ca}^{2+}$ may not be mediated by TRPV6 and CaBP9k. In contrast, dietary $\mathrm{Ca}^{2+}$ deficiency induces the transport and uptake of $\mathrm{Ca}^{2+}$, an increase that correlated with dramatic increases in TRPV6 and CaBP9k expression. Fructose transport and metabolism do not affect these adaptive increases because a low- $\mathrm{Ca}^{2+}$ diet markedly upregulated $\mathrm{Ca}^{2+}$ transport as well as TRPV6 and $\mathrm{CaBP} 9 \mathrm{k}$ expression in wild-type, $\mathrm{KHK}^{-1-}$, and $\mathrm{GLUT5}^{-1-}$ mice. We have previously shown that excessive fructose consumption by wild-type mice inhibits renal synthesis of
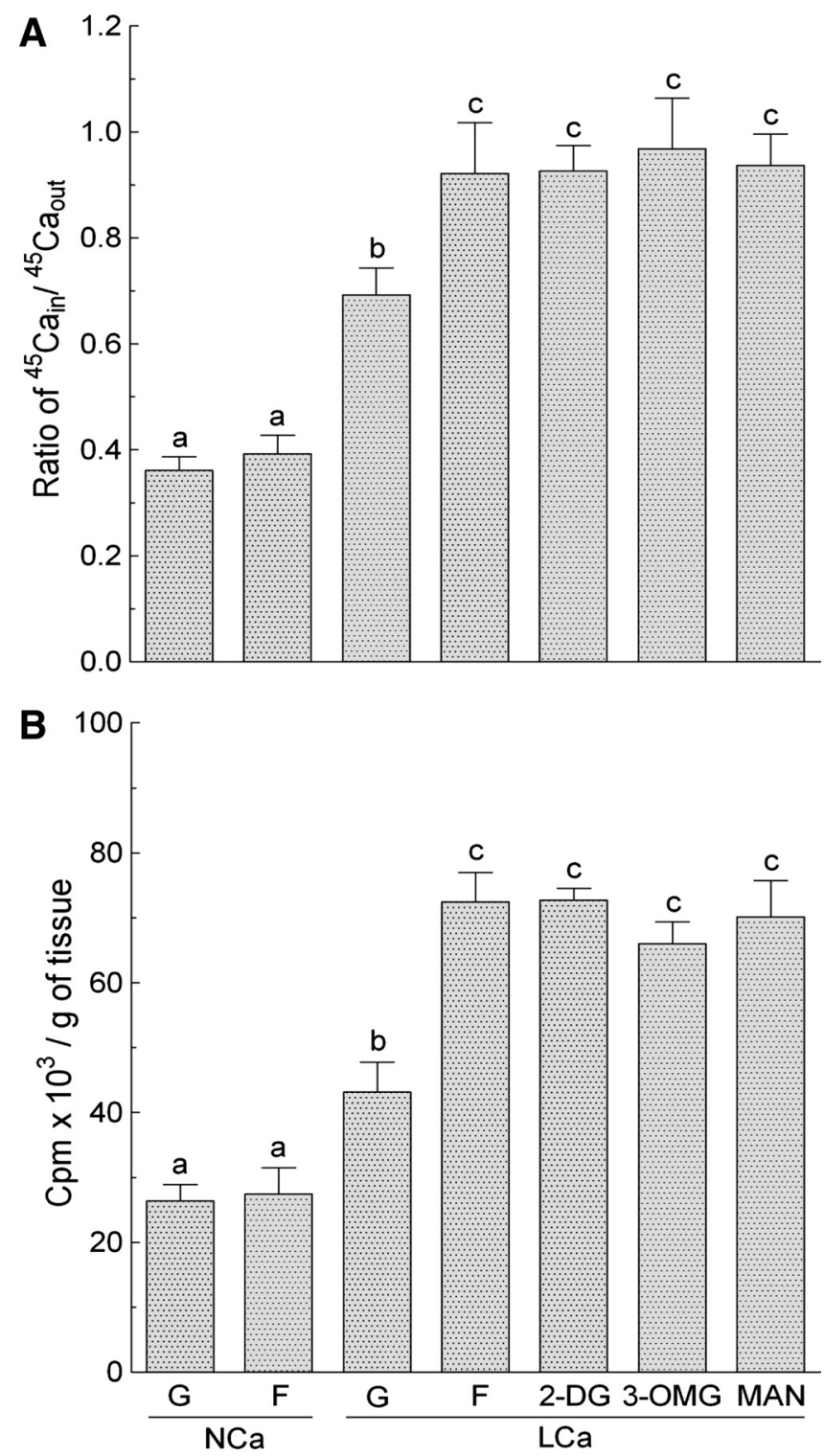

Fig. 7. The acute effects of glucose metabolism and glucose-induced transmembrane depolarization on $\mathrm{Ca}^{2+}$ fluxes were examined in everted sacs obtained from wild-type mice then incubated in buffer containing $10 \mathrm{mM}$ glucose $(\mathrm{G})$, fructose $(\mathrm{F}), 2$-deoxy-D-glucose (2-DG), 3-O-methylglucose (3OMG), or mannitol (MAN) on intestinal $\mathrm{Ca}^{2+}$ transepithelial transport $(A)$ and mucosal uptake $(B)$. 2DG and 3-OMG are nonmetabolized analogs of glucose that can be transported by GLUT5 and SGLT1, respectively. Mannitol is a sugar alcohol that is not transported and not metabolized. The composition of the luminal solution outside the sac is exactly the same as that inside except tracer ${ }^{45} \mathrm{Ca}^{2+}$ was added to luminal side. Values are means $\pm \operatorname{SE}(n=4-6)$. Different letters denote significant $(P<0.05)$ differences. A low- $\mathrm{Ca}^{2+}$ diet clearly induces intestinal $\mathrm{Ca}^{2+}$ transport. Acute incubation with glucose but not fructose, 3-OMG, 2-DG, and MAN reduces the diet-induced component of intestinal $\mathrm{Ca}^{2+}$ transport.

$1,25(\mathrm{OH})_{2} \mathrm{D}_{3}$, thereby compromising their ability to enhance intestinal $\mathrm{Ca}^{2+}$ transport during $\mathrm{Ca}^{2+}$ stress $(21,24,25)$. Here we show that, in mice fed diets with low levels of fructose, the absence of KHK and GLUT5 does not interfere with the induction of intestinal $\mathrm{Ca}^{2+}$ transport by a low- $\mathrm{Ca}^{2+}$ diet.

Acute interactions of diet-induced, active $\mathrm{Ca}^{2+}$ transport with luminal fructose. Although there is an alternative hypothesis regarding fructose transport across the intestinal apical 
membrane that involves, not only GLUT5, but also GLUT2 as well (47), we and others (4) found that GLUT5 ${ }^{-1-}$ mice cannot absorb fructose and would die if given dietary fructose, suggesting an absence or ineffective distribution of GLUT2 in the apical membrane and that GLUT5 is clearly the main transporter mediating fructose transport from the intestinal lumen. Fructose transport occurs mainly in the proximal regions of rat and mouse intestines $(13,61)$, paralleling the regional distribution of GLUT5 (22) and KHK expression, which is modestly reduced in the distal intestine. Many studies have already shown ATP concentrations to decrease markedly in enterocytes and hepatocytes exposed to fructose $(33,38,45,49,54)$. Here we show that this well-known fructose-induced decrease in concentrations of high-energy intermediates like ATP may be highly dependent on the metabolism of fructose by KHK.

TRPV6 expression resembles that of $\mathrm{CaBP} 9 \mathrm{k}$ and is greatest in the duodenum and corresponds to the location of the vitamin $\mathrm{D}$ receptor that regulates intestinal $\mathrm{Ca}^{2+}$ transport (57). We previously showed that active, diet-inducible $\mathrm{Ca}^{2+}$ transport parallels this marked proximal to distal gradient in $\mathrm{Ca}^{2+}$ transporter expression $(21,25)$. The magnitude of $\mathrm{CaBP} 9 \mathrm{k}$ expression is directly proportional to the rate of transcellular $\mathrm{Ca}^{2+}$ transport, and in fact there are arguments that intracellular diffusion of $\mathrm{Ca}^{2+}$ bound to $\mathrm{CaBP} 9 \mathrm{k}$ is the rate-limiting step of active $\mathrm{Ca}^{2+}$ transport (see review in Ref. 40). The sparse, heterogeneous distribution of CaBP9k along the villus in mice fed normal $\mathrm{Ca}^{2+}$ contrasts with the homogeneous distribution of KHK and suggests that some villus cells that metabolize fructose may not be capable of efficiently transporting $\mathrm{Ca}^{2+}$, a condition that changes when mice are fed low $\mathrm{Ca}^{2+}$ as shown in Fig. $2 A$.

Although fructose transport and metabolism as well as $\mathrm{Ca}^{2+}$ transport can occur in the same enterocyte, diet-induced $\mathrm{Ca}^{2+}$ transport clearly is not affected by fructose metabolism and acute fructose-induced reductions in ATP concentrations because 1) transcellular $\mathrm{Ca}^{2+}$ transport remains unchanged with or without supplementation with glutamine, a major source of respiratory fuel and metabolic energy for intestinal cells (17, $58,74)$, and 2) $\mathrm{Ca}^{2+}$ transport is greater in fructose- compared with glucose-incubated sacs from $\mathrm{KHK}^{-1-}$ and GLUT5 ${ }^{-1-}$ mice.

Earlier studies directly comparing acute effects of glucose and fructose on $\mathrm{Ca}^{2+}$ transport in everted ileal sacs of rats seem to support our findings. Although these rats were likely fed normal- $\mathrm{Ca}^{2+}$ diets and high $\mathrm{Ca}^{2+}$ concentrations were used during incubation, transport of $45 \mathrm{mM} \mathrm{Ca}^{2+}$ was greater in 550 $\mathrm{mM}$ fructose than that in glucose (69). Uptake of $0.1 \mathrm{mM}$ $\mathrm{Ca}^{2+}$, a low concentration that favors active transcellular uptake, in $160 \mathrm{mM}$ fructose was greater than that in glucose (3). Total intestinal $\mathrm{Ca}^{2+}$ absorption in vivo, determined acutely by femur uptake of ${ }^{45} \mathrm{Ca}^{2+}$, increased proportionally with increasing concentrations of honey, which is composed mostly of fructose (2).

Acute interactions of diet-induced $\mathrm{Ca}^{2+}$ transport with luminal glucose. Because SGLT1 ${ }^{-1-}$ mice develop glucosegalactose malabsorption syndrome (34), a condition also observed in humans with defects in SGLT1 (72), SGLT1 must be primarily responsible for glucose and galactose uptake into the intestinal cells. Glucose enters the cell via SGLT1, depolarizing the membrane, and can be metabolized in the enterocyte cytosol, which contains all enzymes involved in glycolysis
(62). Glucose metabolism is dependent on luminal glucose concentrations as well as satiety state $(15,44)$. Because SGLT1 is expressed mainly in the enterocytes lining the villi of the proximal regions of mouse and rat intestines (30) already shown to express $\mathrm{CaBP9k}$, transcellular glucose and CaBP9kmediated $\mathrm{Ca}^{2+}$ transport can interact.

The inhibitory effect of glucose on diet-induced increases in $\mathrm{Ca}^{2+}$ transport is not due to glucose-induced changes in membrane potential reducing the downhill electrical gradient for $\mathrm{Ca}^{2+}$ because $\mathrm{Ca}^{2+}$ transport remains high in sacs incubated in $10 \mathrm{mM} 3-O$-methylglucose also transported by SGLT1 and thus also depolarizes the membrane (72). It is possible that glucose and 3-O-methylglucose have different absorption characteristics via SGLT1 and the difference in the effect on $\mathrm{Ca}^{2+}$ transport between the glucose- and 3-O-methylglucose-incubated sacs may not be solely due to the nonmetabolizable nature of 3-O-methylglucose but also to this difference in absorption kinetics. However, the effect of 3-O-methylglucose on $\mathrm{Ca}^{2+}$ transport is similar to those of mannitol and of 2-deoxy-D-glucose, suggesting that the different effect on $\mathrm{Ca}^{2+}$ transport between 3-O-methylglucose and glucose is less likely due to differences in absorption properties but more likely due to differences in metabolic attributes. This conclusion can be confirmed in future work in mouse models without ratelimiting glycolytic enzymes (e.g., hexokinase) and transporters (e.g., SGLT1) in the small intestine.

CaBP9k and KHK distribution along intestinal villus axis. An unexpected finding in this study is the consistently heterogeneous, seemingly punctuate, distribution of $\mathrm{CaBP} 9 \mathrm{k}$ in the intestinal mucosa of mice and rats fed normal $\mathrm{Ca}^{2+}$. The study of Lee et al. (50) and Taylor and Wasserman (64) had similar findings, but the latter ascribed the immunoreactivity to goblet cells. The heterogeneous crypt-villus distribution of CaBP9k that decreases sharply in distal intestinal regions contrasts with that of KHK, which is more homogeneous and still modestly expressed distally. Other studies found CaBP9k-immunoreactive sites to be homogeneously distributed in the villi of rabbit (39), chick (66), and human (37) intestines, so perhaps our findings are limited to mice and rats fed sufficient levels of dietary $\mathrm{Ca}^{2+}$.

Feeding with low- $\mathrm{Ca}^{2+}$ diets seems to increase the number of CaBP9k-containing cells as well as the expression of CaBP9k protein in many cells. This is understandable because CaBP9k expression is regulated by vitamin $\mathrm{D}(8)$, whose levels increase with $\mathrm{Ca}^{2+}$ deficiency, and the vitamin D receptor appears to be homogeneously expressed in all cells lining the intestinal villi $(57,70)$. The heterogeneous $\mathrm{CaBP} 9 \mathrm{k}$ distribution along the villus suggests that, in Ca-sufficient rodents, $\mathrm{CaBP} 9 \mathrm{k}$ is not significantly expressed in some enterocytes that may have the vitamin D receptor. Future work should confirm and evaluate the graded $\mathrm{CaBP} 9 \mathrm{k}$ response of the rodent intestine to $\mathrm{Ca}^{2+}$ sufficiency.

Chronic vs. acute effects of sugars on intestinal $\mathrm{Ca}^{2+}$ transport. We previously showed that, in rats and mice with high $\mathrm{Ca}^{2+}$ requirements (e.g., during lactation) or that are nutritionally deficient in $\mathrm{Ca}^{2+}$, compensatory increases in $1,25-(\mathrm{OH})_{2} \mathrm{D}_{3}-$ regulated intestinal $\mathrm{Ca}^{2+}$ absorption is strongly inhibited by chronic consumption of dietary fructose $(21,24,25)$. The mechanism underlying this chronic fructose effect is a fructose-induced decrease in levels of $1 \alpha$-hydroxylase, the enzyme synthesizing $1,25-(\mathrm{OH})_{2} \mathrm{D}_{3}$. Interestingly, we show in our cur- 
rent study that fructose has no acute effect on diet-induced, $1,25-(\mathrm{OH})_{2} \mathrm{D}_{3}$-regulated $\mathrm{Ca}^{2+}$ transport; rather, glucose metabolism by enterocytes may acutely inhibit this diet-induced component of intestinal $\mathrm{Ca}^{2+}$ absorption. Clearly, additional studies need to be done to increase our understanding of dietary sugar- $\mathrm{Ca}^{2+}$ interactions, in light of increased sugar and decreased $\mathrm{Ca}^{2+}$ consumption by many Americans (55).

\section{ACKNOWLEDGMENTS}

This study was in partial fulfillment for a PhD in Exercise Science, Mahidol University, Thailand. We are deeply indebted to Guoqiang Wang for help in the ATP assays, Luke Fritsky for help during confocal microscopy and image analysis, Prof. Tibor Rohacs for valuable discussion regarding TRPV6, Prof. Narattaphol Charoenphandhu for valuable advice, and Prof. Sylvia Christakos for the generous gift of $\mathrm{CaBP} 9 \mathrm{k}^{-1-}$ mice.

\section{GRANTS}

This work was supported by the National Science Foundation (IOS1121049 to R. Ferraris) and the Program Strategic Scholarships for Frontier Research Network for the Joint Ph.D. Program Thai Doctoral Degree, Office of the Higher Education Commission, Thailand (to P. Tharabenjasin).

\section{DISCLOSURES}

No conflicts of interest, financial or otherwise, are declared by the authors.

\section{AUTHOR CONTRIBUTIONS}

Author contributions: P.T., V.D., and R.P.F. conception and design of research; P.T., V.D., C.P., R.J.J., and J.Z. performed experiments; P.T., V.D., C.P., and R.P.F. analyzed data; P.T., V.D., and R.P.F. interpreted results of experiments; P.T. prepared figures; P.T. and R.P.F. drafted manuscript; P.T., V.D., C.P., N.K., R.J.J., J.Z., and R.P.F. approved final version of manuscript; V.D., N.K., R.J.J., and R.P.F. edited and revised manuscript.

\section{REFERENCES}

1. Allen LH. Calcium bioavailability and absorption: a review. Am J Clin Nutr 35: 783-808, 1982.

2. Ariefdjohan MW, Martin BR, Lachcik PJ, Weaver CM. Acute and chronic effects of honey and its carbohydrate constituents on calcium absorption in rats. J Agric Food Chem 56: 2649-2654, 2008.

3. Armbrecht HJ, Wasserman RH. Enhancement of $\mathrm{Ca}++$ uptake by lactose in the rat small intestine. J Nutr 106: 1265-1271, 1976.

4. Barone S, Fussell SL, Singh AK, Lucas F, Xu J, Kim C, Wu X, Yu Y, Amlal H, Seidler U, Zuo J, Soleimani M. Slc2a5 (Glut5) is essential for the absorption of fructose in the intestine and generation of fructoseinduced hypertension. J Biol Chem 284: 5056-5066, 2009.

5. Benn BS, Ajibade D, Porta A, Dhawan P, Hediger M, Peng JB, Jiang Y, Oh GT, Jeung EB, Lieben L, Bouillon R, Carmeliet G, Christakos S. Active intestinal calcium transport in the absence of transient receptor potential vanilloid type 6 and calbindin-D9k. Endocrinology 149: $3196-$ 3205, 2008.

6. Boass A, Lovdal JA, Toverud SU. Pregnancy- and lactation-induced changes in active intestinal calcium transport in rats. Am J Physiol Gastrointest Liver Physiol 263: G127-G134, 1992.

7. Bray GA, Nielsen SJ, Popkin BM. Consumption of high-fructose corn syrup in beverages may play a role in the epidemic of obesity. Am J Clin Nutr 79: 537-543, 2004.

8. Bronner F, Pansu D, Stein WD. An analysis of intestinal calcium transport across the rat intestine. Am J Physiol Gastrointest Liver Physiol 250: G561-G569, 1986.

9. Camara-Martos F, Amaro-Lopez MA. Influence of dietary factors on calcium bioavailability: a brief review. Biol Trace Elem Res 89: 43-52, 2002.

10. Cardaci S, Desideri E, Ciriolo MR. Targeting aerobic glycolysis: 3-bromopyruvate as a promising anticancer drug. J Bioenerg Biomembr 44: 17-29, 2012.

11. Carroll KM, Wood RJ, Chang EB, Rosenberg IH. Glucose enhancement of transcellular calcium transport in the intestine. Am J Physiol Gastrointest Liver Physiol 255: G339-G345, 1988.
12. Casirola DM, Ferraris RP. alpha-Glucosidase inhibitors prevent dietinduced increases in intestinal sugar transport in diabetic mice. Metabolism 55: 832-841, 2006.

13. Casirola DM, Ferraris RP. Role of the small intestine in postpartum weight retention in mice. Am J Clin Nutr 78: 1178-1187, 2003.

14. Chang YO, Hegsted DM. Lactose and calcium transport in gut sacs. $J$ Nutr 82: 297-300, 1964.

15. Cherbuy C, Darcy-Vrillon B, Posho L, Vaugelade P, Morel MT, Bernard F, Leturque A, Penicaud L, Duee PH. GLUT2 and hexokinase control proximodistal gradient of intestinal glucose metabolism in the newborn pig. Am J Physiol Gastrointest Liver Physiol 272: G1530G1539, 1997.

16. Christakos S, Dhawan P, Porta A, Mady LJ, Seth T. Vitamin D and intestinal calcium absorption. Mol Cell Endocrinol 347: 25-29, 2011.

17. Costa C, Huneau J, Tome D. Characteristics of L-glutamine transport during Caco-2 cell differentiation. Biochim Biophys Acta 1509: 95-102, 2000.

18. Cura AJ, Carruthers A. The role of monosaccharide transport proteins in carbohydrate assimilation, distribution, metabolism and homeostasis. Compr Physiol 2: 863-914, 2012.

19. Diggle CP, Shires M, McRae C, Crellin D, Fisher J, Carr IM, Markham AF, Hayward BE, Asipu A, Bonthron DT. Both isoforms of ketohexokinase are dispensable for normal growth and development. Physiol Genomics 42A: 235-243, 2010.

20. Dorkkam N, Wongdee K, Suntornsaratoon P, Krishnamra N, Charoenphandhu N. Prolactin stimulates the L-type calcium channelmediated transepithelial calcium transport in the duodenum of male rats. Biochem Biophys Res Commun 430: 711-716, 2013.

21. Douard V, Asgerally A, Sabbagh Y, Sugiura S, Shapses SA, Casirola D, Ferraris RP. Dietary fructose inhibits intestinal calcium absorption and induces vitamin D insufficiency in CKD. J Am Soc Nephrol 21: 261-271, 2010.

22. Douard V, Choi HI, Elshenawy S, Lagunoff D, Ferraris RP. Developmental reprogramming of rat GLUT5 requires glucocorticoid receptor translocation to the nucleus. J Physiol 586: 3657-3673, 2008.

23. Douard V, Ferraris RP. The role of fructose transporters in diseases linked to excessive fructose intake. J Physiol 591: 401-414, 2013.

24. Douard V, Sabbagh Y, Lee J, Patel C, Kemp FW, Bogden JD, Lin S, Ferraris RP. Excessive fructose intake causes 1,25-(OH)2D3-dependent inhibition of intestinal and renal calcium transport in growing rats. Am J Physiol Endocrinol Metab 304: E1303-E1313, 2013.

25. Douard V, Suzuki T, Sabbagh Y, Lee J, Shapses S, Lin S, Ferraris RP. Dietary fructose inhibits lactation-induced adaptations in rat 1,25$(\mathrm{OH})(2) \mathrm{D}(3)$ synthesis and calcium transport. FASEB $J$ 26: 707-721, 2012.

26. Dowdle EB, Schachter D, Schenker H. Requirement for vitamin D for the active transport of calcium by the intestine. Am J Physiol 198: 269-274, 1960.

27. Favus MJ, Angeid-Backman E. Effects of lactose on calcium absorption and secretion by rat ileum. Am J Physiol Gastrointest Liver Physiol 246: G281-G285, 1984.

28. Ferraris RP, Casirola DM, Vinnakota RR. Dietary carbohydrate enhances intestinal sugar transport in diabetic mice. Diabetes 42: 1579 1587, 1993.

29. Ferraris RP, Diamond J. Regulation of intestinal sugar transport. Physiol Rev 77: 257-302, 1997.

30. Ferraris RP, Villenas SA, Hirayama BA, Diamond J. Effect of diet on glucose transporter site density along the intestinal crypt-villus axis. Am J Physiol Gastrointest Liver Physiol 262: G1060-G1068, 1992.

31. Ferraris RP, Yasharpour S, Lloyd KC, Mirzayan R, Diamond JM. Luminal glucose concentrations in the gut under normal conditions. Am J Physiol Gastrointest Liver Physiol 259: G822-G837, 1990.

32. Fleet JC, Schoch RD. Molecular mechanisms for regulation of intestinal calcium absorption by vitamin D and other factors. Crit Rev Clin Lab Sci 47: 181-195, 2010.

33. Ginsburg V, Hers HG. On the conversion of fructose to glucose by guinea pig intestine. Biochim Biophys Acta 38: 427-434, 1960.

34. Gorboulev V, Schurmann A, Vallon V, Kipp H, Jaschke A, Klessen D, Friedrich A, Scherneck S, Rieg T, Cunard R, Veyhl-Wichmann M, Srinivasan A, Balen D, Breljak D, Rexhepaj R, Parker HE, Gribble FM, Reimann F, Lang F, Wiese S, Sabolic I, Sendtner M, Koepsell H. $\mathrm{Na}(+)$-D-glucose cotransporter SGLT1 is pivotal for intestinal glucose absorption and glucose-dependent incretin secretion. Diabetes 61: 187196, 2012. 
35. Gueguen L, Pointillart A. The bioavailability of dietary calcium. $J$ Am Coll Nutr 19: 119S-136S, 2000.

36. Hanover LM, White JS. Manufacturing, composition, and applications of fructose. Am J Clin Nutr 58: 724S-732S, 1993.

37. Helmke K, Federlin K, Piazolo P, Stroder J, Jeschke R, Franz HE. Localization of calcium-binding protein in intestinal tissue by immunofluorescence in normal, vitamin-D-deficient and uraemic subjects. Gut 15: 875-879, 1974.

38. Herman RH, Stifel FB, Greene HL, Herman YF. Intestinal metabolism of fructose. Acta Med Scand Suppl 542: 19-25, 1972.

39. Hoenderop JG, Hartog A, Stuiver M, Doucet A, Willems PH, Bindels RJ. Localization of the epithelial $\mathrm{Ca}(2+)$ channel in rabbit kidney and intestine. J Am Soc Nephrol 11: 1171-1178, 2000.

40. Hoenderop JG, Nilius B, Bindels RJ. Calcium absorption across epithelia. Physiol Rev 85: 373-422, 2005.

41. Ishimoto T, Lanaspa MA, Le MT, Garcia GE, Diggle CP, Maclean PS, Jackman MR, Asipu A, Roncal-Jimenez CA, Kosugi T, Rivard CJ, Maruyama S, Rodriguez-Iturbe B, Sanchez-Lozada LG, Bonthron DT, Sautin YY, Johnson RJ. Opposing effects of fructokinase C and A isoforms on fructose-induced metabolic syndrome in mice. Proc Natl Acad Sci USA 109: 4320-4325, 2012.

42. Jiang L, David ES, Espina N, Ferraris RP. GLUT-5 expression in neonatal rats: crypt-villus location and age-dependent regulation. Am $J$ Physiol Gastrointest Liver Physiol 281: G666-G674, 2001.

43. Jiang L, Ferraris RP. Developmental reprogramming of rat GLUT-5 requires de novo mRNA and protein synthesis. Am J Physiol Gastrointest Liver Physiol 280: G113-G120, 2001.

44. Jones GM, Mayer RJ. Glucose metabolism in the rat small intestine: the effect of glucose analogues on hexokinase activity. Biochem $J$ 132: 125-128, 1973.

45. Karczmar GS, Kurtz T, Tavares NJ, Weiner MW. Regulation of hepatic inorganic phosphate and ATP in response to fructose loading: an in vivo 31P-NMR study. Biochim Biophys Acta 1012: 121-127, 1989.

46. Kellett GL. Alternative perspective on intestinal calcium absorption: proposed complementary actions of $\mathrm{Ca}(\mathrm{v}) 1.3$ and TRPV6. Nutr Rev 69: 347-370, 2011.

47. Kellett GL, Brot-Laroche E, Mace OJ, Leturque A. Sugar absorption in the intestine: the role of GLUT2. Annu Rev Nutr 28: 35-54, 2008.

48. Kles KA, Wallig MA, Tappenden KA. Luminal nutrients exacerbate intestinal hypoxia in the hypoperfused jejunum. JPEN J Parenter Enteral Nutr 25: 246-253, 2001.

49. Lamers JM, Hulsmann WC. The effect of fructose on the stores of energy-rich phosphate in rat jejunum in vivo. Biochim Biophys Acta 313: $1-8,1973$.

50. Lee GS, Lee KY, Choi KC, Ryu YH, Paik SG, Oh GT, Jeung EB. Phenotype of a calbindin-D9k gene knockout is compensated for by the induction of other calcium transporter genes in a mouse model. $J$ Bone Miner Res 22: 1968-1978, 2007.

51. Lengemann FW, Comar CL, Wasserman RH. Absorption of calcium and strontium from milk and nonmilk diets. J Nutr 61: 571-583, 1957.

52. Lengemann FW, Wasserman RH, Comar CL. Studies on the enhancement of radiocalcium and radiostrontium absorption by lactose in the rat. J Nutr 68: 443-456, 1959.

53. Manolescu AR, Witkowska K, Kinnaird A, Cessford T, Cheeseman C. Facilitated hexose transporters: new perspectives on form and function. Physiology (Bethesda) 22: 234-240, 2007.

54. Mavrias DA, Mayer RJ. Metabolism of fructose in the small intestine. 1. The effect of fructose feeding on fructose transport and metabolism in rat small intestine. Biochim Biophys Acta 291: 531-537, 1973.
55. Nicklas TA, O'Neil CE, Fulgoni VL 3rd. The role of dairy in meeting the recommendations for shortfall nutrients in the American diet. $J$ Am Coll Nutr 28, Suppl 1: 73S-81S, 2009.

56. Oba M, Baldwin RLt, Bequette BJ. Oxidation of glucose, glutamate, and glutamine by isolated ovine enterocytes in vitro is decreased by the presence of other metabolic fuels. J Anim Sci 82: 479-486, 2004.

57. Palm C, Hartmann K, Weber K. Expression and immunolocalization of calcium transport proteins in the canine duodenum, kidney, and pancreas. Anat Rec (Hoboken) 293: 770-774, 2010.

58. Porteous JW. Intestinal metabolism. Environ Health Perspect 33: 25-35, 1979.

59. Schachter D, Dowdle EB, Schenker H. Active transport of calcium by the small intestine of the rat. Am J Physiol 198: 263-268, 1960.

60. Schuette SA, Knowles JB, Ford HE. Effect of lactose or its component sugars on jejunal calcium absorption in adult man. Am J Clin Nutr 50: 1084-1087, 1989.

61. Solberg DH, Diamond JM. Comparison of different dietary sugars as inducers of intestinal sugar transporters. Am J Physiol Gastrointest Liver Physiol 252: G574-G584, 1987.

62. Srivastava LM, Hubscher G. Glucose metabolism in the mucosa of the small intestine. Glycolysis in subcellular preparations from the cat and rat. Biochem J 100: 458-466, 1966.

63. Suzuki T, Douard V, Mochizuki K, Goda T, Ferraris RP. Diet-induced epigenetic regulation in vivo of the intestinal fructose transporter Glut5 during development of rat small intestine. Biochem J 435: 43-53, 2011.

64. Taylor AN, Wasserman RH. Immunofluorescent localization of vitamin D-dependent calcium-binding protein. J Histochem Cytochem 18: $107-$ $115,1970$.

65. Thorens B, Mueckler M. Glucose transporters in the 21st Century. Am J Physiol Endocrinol Metab 298: E141-E145, 2010.

66. Thorens B, Roth J, Norman AW, Perrelet A, Orci L. Immunocytochemical localization of the vitamin D-dependent calcium binding protein in chick duodenum. $J$ Cell Biol 94: 115-122, 1982.

67. Turner JD, Gaspers LD, Wang G, Thomas AP. Uncoupling protein-2 modulates myocardial excitation-contraction coupling. Circ Res 106: 730-738, 2010.

68. van den Berghe G, Bronfman M, Vanneste R, Hers HG. The mechanism of adenosine triphosphate depletion in the liver after a load of fructose. A kinetic study of liver adenylate deaminase. Biochem J 162: 601-609, 1977.

69. Vaughan OW, Filer LJ Jr. The enhancing action of certain carbohydrates on the intestinal absorption of calcium in the rat. $J$ Nutr 71: 10-14, 1960.

70. Wang Y, Zhu J, DeLuca HF. Where is the vitamin D receptor? Arch Biochem Biophys 523: 123-133, 2012.

71. Woods HF, Eggleston LV, Krebs HA. The cause of hepatic accumulation of fructose 1-phosphate on fructose loading. Biochem J 119: 501-510, 1970.

72. Wright EM, Loo DD, Hirayama BA. Biology of human sodium glucose transporters. Physiol Rev 91: 733-794, 2011.

73. Wu X, Wang X, Gao J, Yu Y, Jia S, Zheng J, Dallos P, He DZ, Cheatham M, Zuo J. Glucose transporter 5 is undetectable in outer hair cells and does not contribute to cochlear amplification. Brain Res 1210: $20-28,2008$

74. Yang H, Soderholm JD, Larsson J, Permert J, Lindgren J, Wiren M. Bidirectional supply of glutamine maintains enterocyte ATP content in the in vitro using chamber model. Int J Colorectal Dis 15: 291-296, 2000.

75. Younoszai MK, Nathan R. Intestinal calcium absorption is enhanced by D-glucose in diabetic and control rats. Gastroenterology 88: 933-938, 1985 